\title{
Geology and \\ Uranium Deposits in \\ Carbonaceous Rocks of the \\ Fall Creek Area, \\ Bonneville County, Idaho
}

By James D. Vine

Trace Elements Investigations Report 451

UNITED STATES DEPARTMENT OF THE INTERIOR GEOLOGICAL SURVEY 


$$
\begin{aligned}
& 328 \times 2,0600
\end{aligned}
$$

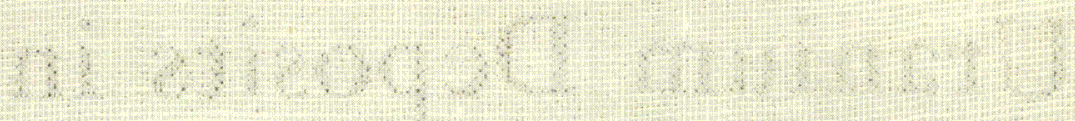

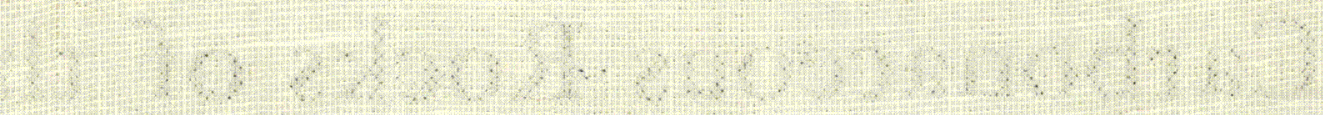

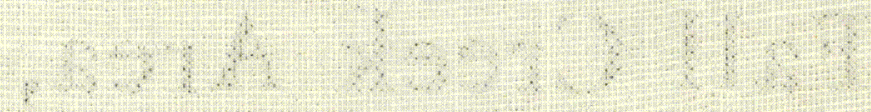

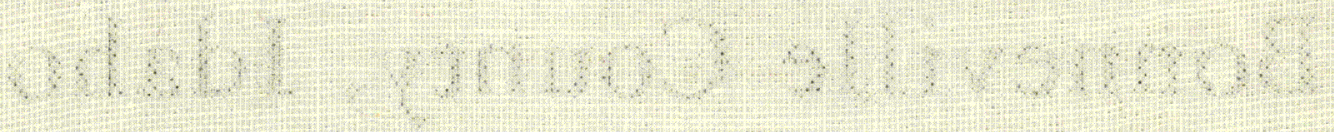


Geology and Mineralogy

This document consists of 70 pages plus 2 figures.

Series A

UNITED STATES DEPARTMENT OF THE INTERIOR

GEOLOGICAL SURVEY

GEOLOGY AND URANIUM DEPOSITS IN CARBONACEOUS ROCKS

OF THE FALL CREEK AREA, BONNEVILLE COUNTY, IDAHO*

By

James D. Vine

July 1954

Trace Elements Investigations Report 451

This preliminary report is distributed without editorial and technical review for conformity with official standards and nomenclature. It is not for public inspection or quotation.

* This report concerns work done on behalf of the Division of Raw Materials of the U.S. Atomic Energy Commission. 
USGS - TEI-45I

GEOLOGY AND MINERALOGY

Distribution (Series A)

No. of copies

Argonne National Laboratory

Atomic Energy Commission, Washington

Battelle Memorial Institute, Columbus

Carbide and Carbon Chemicals Company, $\mathrm{Y}-12$ area

Division of Raw Materials, Albuquerque .

Division of Raw Materials, Butte.

Division of Raw Materials, Denver

Division of Raw Materials, Douglas

Division of Raw Materials, Hot Springs

Division of Raw Materials, Ishpeming

Division of Raw Materials, Phoenix

Division of Raw Materials, Richfield

Division of Raw Materials, Salt Lake City

Division of Raw Materials, Washington

Dow Chemical Company, Pittsburg .

Exploration Division, Grand Junction Operations Office

Grand Junction Operations Office.

National Lead Company, Wincheste

Technical Information Service, Oak Ridge

Tennessee Valley Authority, Wilson Dam

U. S. Geological Survey:

Alaskan Geology Branch, Menlo Park . . . . . . . . .

Fuels Branch, Washington . . . . . . . . . . . . 3

Geochemistry and Petrology Branch, Washington . . . . 1

Geophysics Branch, Washington . . . . . . . . . . . 1

Mineral Deposits Branch, Washington

E. H. Bailey, Menlo Park

A. L. Brokaw, Grand Junction

P. C. Patton, Denver

J. R. Cooper, Denver

N. M. Denson, Denver

C. E. Dutton, Madison

W. L. Emerick, Plant City

L. S. Gardner, Albuquerque

M. R. Klepper, Spokane

A. H. Koschmann, Denver

R. A. Laurence, Knoxville

D. M. Lemmon, Washington

J. D. Love, Laramie .

V. E. McKelvey, Menlo Park

J. F. Powers, Salt Lake City

Q. D. Singewald, Beltsville

J. F. Smith, Jr., Denver

A. E. Weissenborn, Spokane

TEPCO, RPS, Washington (Including master). 
Abstract . • . . . . . . . . . . . . . • •

Introduction . . . . . . . . . . . . . . . . . .

Purpose and scope of the report . . . . . . . 7

Acknowledgments . . . . . . . . . . . . . 8

Location and accessibility . . . . . . . . . . . 9

Topography and water supply . . . . . . . . . . 11

Land ownership. . . . . . . . . . . . . . . . 11

General geologic features . . . . . . . . . . . . . 11

Sedimentary rocks . . . . . . . . . . . 11

Jurassic system . . . . . . . . . . 13

Nugget sandstone . . . . . . . . . . . . 13

Twin Creek lime stone . . . . . . . . . . 13

Preuss formation . . . . . . . . . 13

Stump formation . . . . . . . . . . 13

Cretaceous system . . . . . . . . . . . 14

Gannett group . . . . . . . . . . . 14

Ephraim formation . . . . . . . . . . 14

Peterson limestone . . . . . . . . . . . 14

Bechler formation . . . . . . . . . . . 14

Draney limestone . . . . . . . . . . 15

Tyge formation . . . . . . . . . . 15

Bear River formation . . . . . . . . . 17

Wayan formation . . . . . . . . . . 18

Igneous rocks . . . . . . . . . . . . . . 19

Structural setting . . . . . . . . . . . . . . . 20

Structural and geographic distribution of the Bear River

formation . . . . . . . . . . . . . 21

Uranium accurrences . . . . . . . . . . . . . 23

General distribution . . . . . . . . . . . 23

Fall Creek coal prospect . . . . . . . . . . . 25

Distribution of uranium and other minor elements in carbonaceous material . . . . . . . . . . . . . . . . 32

Origin of the uranium occurrences . . . . . . . . 37

Results of core drilling . . . . . . . . . . . . 44

Drilling operations . . . . . . . . . . . . . 44

Purpose . . . . . . . . . . . . . . . 44

Areas drilled . . . . . . . . . . . . . 44

Drilling contract ............ . 46

Equipment . . . . . . . . . . . . . . 46

Drilling progress . . . . . . . . . . 47

Description of core holes . . . . . . . . . 49

Inferred reserves . . . . . . . . . . . . . 51

Literature cited . . . . . . . . . . . . 54

Unpublished reports . . . . . . . . . . . . 54 


\section{ILLUSTRATIONS}

Page

Figure 1. Index map of southeastern Idaho showing location of the Fall Creek area and samples collected jn adjacent areas . . . . . . . 10

2. Geologic map of the Fall Creek area, Bonneville County, Idaho . . . . . . . (In envelope)

3. Longitudinal section and distribution of uranium in samples from the Fall Creek coal prospect, Bonneville County, Idaho . . . . . . . (In envelope)

4. Stratigraphic section of the upper part of the Bear River formation and the lower part of the Wayan formation as measured at the Fall Creek coal prospect . . . . . . 26

5. Comparison of uranium, molybdenum, and germanium content in the ash of coal . . . 36

6. Sketch map of part of Fall Creek area, Bonneville County, Idaho, showing location of core holes and areas used to estimate reserves of uranium-bearing rock $\cdot$. .

7. Stratigraphic sections of cores from Fall Creek area, Idaho . . . . . . . .

\section{TABLES}

Table 1. Sedimentary rocks exposed in the Fall Creek area

2. Coal analyses of samples from the Fall Creek coal prospect. . . . . . . . . . .

3. Inferred reserves of uranium in the Fall Creek area 


\section{APPENDIX}

Analyses of samples collected from the Fall Creek and

Page adjacent areas

Table A. Analyses of carbonaceous rocks in the Bear

River formation (except as noted) . . . . . 57

B. Analyses of silicic volcanic rocks . . . . . 65

C. Analyses of natural waters. . . . . . . 66

D. Core analyses . . . . . . . . . . . 67

E. Semi-quantitative spectrographic analyses . . 68

F. Standard sensitivities for the elements determined by the semi-quantitative spectrographic method 70 
GEOLOGY AND URANIUM DEPOSITS IN CARBONACEOUS ROCKS

OF THE FALL CREEK AREA, BONNEVILLE COUNTY, IDAHO

By James D. Vine

\section{ABSTRACT}

Uranium occurs in carbonaceous rocks of the Bear River formation of Early Cretaceous age in the Fall Creek area, Bonneville County, Idaho. The principal exposure is at the Fall Creek coal prospect in section 4, T. 1 S., R. 42 E., where impure coal contains as much as 0.1 percent uranium and its ash contains 0.3 percent uranium. Geologic mapping and sampling have demonstrated that the zone of uranium-bearing rocks is widespread in the area and is repeated several times by folding and faulting of the enclosing strata, although exposures suitable for sampling and analysis are few. Analytic data suggests a possible geochemical relation between uranium, germanium, and molybdenum. Four general hypotheses are advanced for the origin of uranium in carbonaceous rocks, a syngenetic, a diagenetic, and two epigenetic hypotheses--one by hydrothermal solutions and a second by downward percolating meteoric solutions. Analogy with other occurrences of uranium-bearing carbonaceous rocks suggests that the epigenetic hypothesis of deposition by downward percolating meteoric water seems best able to explain the occurrence of uranium in the Fall Creek area. Core drilling was inconclusive in demonstrating the areal extent of the 
radioactive units because of the failure of most of the holes to penetrate the uranium-bearing strata. Structural complexity, faulting, thinning of incompetent strata, and increasingly steep dips at depth were factors contributing to the inconclusive results of the drilling.

Inferred reserves are tentatively estimated to be about 1,300 tons of uranium in about six and a half million tons of coaly shale, carbona. ceous shale, and carbonaceous limestone. This estimate is based on the average thickness and grade of uranium-bearing strata exposed in the Fall Creek coal prospect, drill-hole data, and the inferred extent of these strata over an area slightly more than 400 acres in size.

\section{INTRODUCTION}

Purpose and scope of the report

During the course of reconnaissance for uranium-bearing coal and carbonaceous materials during the 1951 field season George W. Moore and the author made many radioactivity measurements of coal mines in Idaho, Colorado, and Utah, especially where the coals were overlain by silicic volcanic rocks. This association was proposed as the possible explanation for the occurrence of uranium in the lignites of western South Dakota by Denson, Bachman, and Zeller (1950). They suggested that the uranium in the lignite was introduced by cold meteoric waters percolating downward from volcanic tuff in the White River formation of Oligocene age and the Arikaree formation of 
Miocene age. Reconnaissance during the 1951 field season was carried on in Idaho and adjacent areas in an attempt to discover additional uranium deposits that might have been formed in a similar manner. Several occurrences were found where the uranium content was too low to be of economic interest (Vine and Moore, 1952b). However, investigations in the Fall Creek area, where Mansfield (1920) had reported several coal prospects closely associated with volcanic rocks, resulted in the discovery of a significant concentration of uranium (Vine and Moore, 1952a).

Field work was carried on during July and August 1952 to determine the areal extent, structural setting, and nature of the occurrence of uranium in the Fall Creek area (Vine, 1953). Core drilling to deter = mine the thickness and grade of the uranium-bearing zone was done during June, Jul.y, and August 1953. This report describes the general geologic setting, the occurrences of uranium or radioactivity in this and adjacent areas, the probable nature of the mineralization and origin of the deposits, and the estimated reserves of uranium-bearing rock.

\section{Acknowledgments}

The field investigations were greatly facilitated by the use of an advance copy of a geologic map of the Irwin and part of the Hell Creek quadrangles prepared by Louis S. Gardner (1952) of the U. S. Geological Survey. The author is indebted to George W. Moore who assisted in the reconnaissance in 1951, Robert F. Flege, Jr. who assisted with 
the geologic mapping during the 1952 field season, and Max L. Troyer who supervised the drilling program. All analytical work was performed in the Washington and Denver laboratories, U. S. Geological Survey. The work was done on behalf of the Division of Raw Materials of the U.S. Atomic Energy Commission.

\section{Location and accessibility}

The uranium-bearing strata of the Fall Creek area are on the west flank of the Caribou Mountains in Bonneville County, Idaho in Tps. $1 \mathrm{~N}$. and 1 S., R. 42 E. (See figs. 1 and 2.) The area is about 16 miles southwest of Swan Valley, Idaho, and is easily accessible in good weath. er. The principal exposure is in the NE $1 / 4 \mathrm{sec} .4, \mathrm{~T} .1 \mathrm{~S} ., \mathrm{R} .42 \mathrm{E}$. , at an abandoned, inclined shaft dug for coal, adjacent to the Fall Creek road in the Caribou National Forest. The abandoned, inclined shaft, referred to as the Fall Creek coal prospect, may be reached as follows: drive 3 miles northwest on U. S. Highway 26 from the town of Swan Valley and cross the bridge that spans the Snake River. At the west side of the bridge turn left onto a graveled road and proceed about a mile along the Snake River to the junction of the Fall Creek road. Turn right and travel about 12 miles up the Fall Creek road. The entrance to the Fall Creek coal prospect is marked by a timbered entry on the south side of the road about a mile beyond the Fall Creek Ranger Station. (See fig. 2.) 


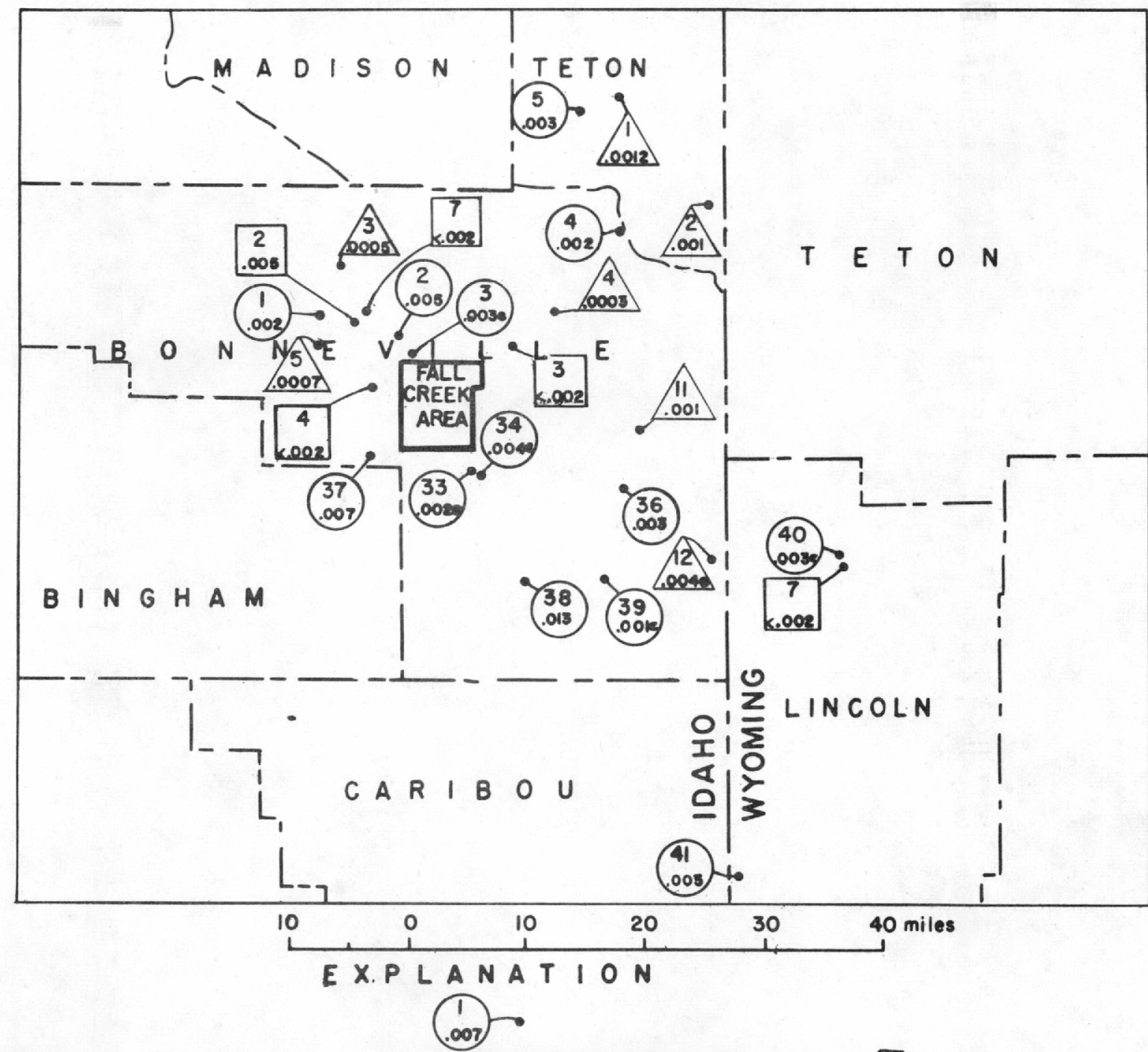

Carbonaceous rock sample locality. Upper figure is locality number. Lower figure is maximum percent uranium (or equivalent uranium if followed by " $e$ ") in sample.

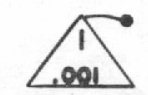

Silicic volcanic rock sample locality. Upper figure is locality number. Lower figure is maximum percent uranium (or eqivalent uranium if followed by " $e$ ") in somple.

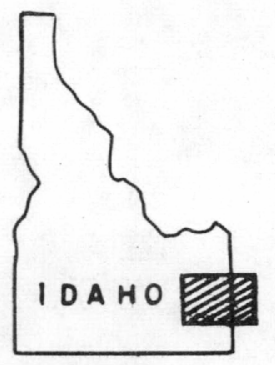

Key Map

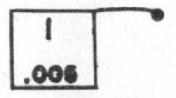

Water sample localify. Upper figure is locality number. Lower figure is amount of uranium in parts per million. 
Topography and water supply

The U. S. Geological Survey Hell Creek and Irwin topographic quad. rangles show altitudes in the Fall Creek area ranging from about 5,600 feet in the valley of Fall Creek to 7,600 feet along the drainage divide between Fall Creek and Pritchard Creek in the northern part of the area. Fall Creek, which flows northeast to the Snake River, drains most of the area although Hell Creek, which flows northwestward into the Snake River, drains most of the southwestern part of the area (fig. 2). Fall, Pritchard, and Hell Creeks and many of their tributaries are permanent streams.

\section{Land ownership}

Except for a tier of sections along its west side, most of the area mapped lies within the boundary of the Caribou National Forest. Several small tracts of privately owned land, however, lie within the National Forest. These tracts are shown on the Department of Agriculture map of the Caribou National Forest dated 1949.

\section{GENERAL GEOLOGIC FEATURES}

\section{Sedimentary rocks}

Strata of Mesozoic and Paleozoic age occur in the Caribou Mountains, but as only Cretaceous and Jurassic rocks are exposed in the area mapped, only the rocks of these systems will be described. A summary of the sedimentary rocks exposed in the area is given in table 1 . The following descriptions are adapted from Kirkham (1924, p. 20-29) with important modifications in the descriptions of the Tygee and Wayan formations in order to include Louis S. Gardner's usage (personal communication) of the Bear River formation. 
Table 1. - Sedimentary rocks exposed in the Fall Creek area $1 /$ Thickness

\begin{tabular}{|c|c|c|c|c|}
\hline & \multicolumn{2}{|c|}{ Formation } & (in feet) & Description \\
\hline 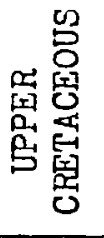 & \multicolumn{2}{|c|}{ Wayan formation } & $\begin{array}{l}3,000-4,000 \\
\text { (estimate) }\end{array}$ & $\begin{array}{l}\text { Shale, red and purple, and sandstone, gray, } \\
\text { medium to coarse agrained, cross-bedded, } \\
\text { friable. Sandstone beds form prominent } \\
\text { ledges in the softer shales. }\end{array}$ \\
\hline \multirow{6}{*}{$\begin{array}{l}c \\
0 \\
0 \\
91 \\
0 \\
4 \\
E \\
1=1 \\
0 \\
0\end{array}$} & \multicolumn{2}{|c|}{$\begin{array}{l}\text { Bear River } \\
\text { formation }\end{array}$} & $300-500$ & $\begin{array}{l}\text { Siltstone, dark gray, carbonaceous, ferrugi- } \\
\text { nous, and brown thin-bedded sandstone in } \\
\text { lower two-thirds, overlain in upper third by } \\
\text { brown to gray medium-grained quartzite or } \\
\text { sandstone that is very resistant to weather- } \\
\text { ing. Uranium-bearing coaly shale and carbo- } \\
\text { naceous limestone occur near the top of the } \\
\text { formation }\end{array}$ \\
\hline & \multirow{5}{*}{ 虫 } & $\begin{array}{l}\text { Tygee } \\
\text { formation }\end{array}$ & $285-300$ & $\begin{array}{l}\text { Shale, red, interbedded with sandstone, gray } \\
\text { to brown, fine-grained; some s andstone is } \\
\text { gray medium-grained, cross bedded and friable. } \\
\text { The sandstone beds form ledges in the shales. }\end{array}$ \\
\hline & & $\begin{array}{l}\text { Draney } \\
\text { limestone }\end{array}$ & $175-300$ & $\begin{array}{l}\text { Limestone, gray, fine- to coarse-grained, } \\
\text { weathers dirty white; fossiliferous at top. }\end{array}$ \\
\hline & & $\begin{array}{l}\text { Bechler } \\
\text { formation }\end{array}$ & $225=300$ & Shale, red, weathers into a red soil. \\
\hline & & $\begin{array}{l}\text { Peterson } \\
\text { limestone }\end{array}$ & 50.100 & $\begin{array}{l}\text { Limestone, fine-grained, dark gray, weathers } \\
\text { dirty white }\end{array}$ \\
\hline & & $\begin{array}{l}\text { Ephraim } \\
\text { formation }\end{array}$ & $360-400$ & $\begin{array}{l}\text { Conglomerate and sandstone, reddish gray, } \\
\text { coarse-grained, gritty with some reddish-gray } \\
\text { shale and purplish-gray limestone. }\end{array}$ \\
\hline 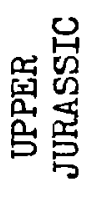 & \multicolumn{2}{|c|}{$\begin{array}{l}\text { Stump } \\
\text { formation }\end{array}$} & $220-300$ & $\begin{array}{l}\text { Sandstone, gray to greenish-gray, fine-grained } \\
\text { and shaly; some sandstone is massive and } \\
\text { coarse-grained. }\end{array}$ \\
\hline \multirow{3}{*}{ 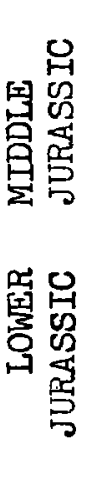 } & \multicolumn{2}{|c|}{$\begin{array}{l}\text { Preuss } \\
\text { formation }\end{array}$} & $425-500$ & $\begin{array}{l}\text { Shale, red and green with green "salt and } \\
\text { pepper" sandstone and thin beds of limestone. }\end{array}$ \\
\hline & \multicolumn{2}{|c|}{$\begin{array}{l}\text { Twin Creek } \\
\text { limestone }\end{array}$} & $970-1,200$ & $\begin{array}{l}\text { Limestone, gray, impure, weathers to a yellow- } \\
\text { ish-gray color, forms small splintery fragments. }\end{array}$ \\
\hline & \multicolumn{2}{|c|}{$\begin{array}{l}\text { Nugget } \\
\text { sand stone }\end{array}$} & 1,000 & $\begin{array}{l}\text { Quartzite and sandstone, red to pink or white, } \\
\text { very resistant, weathers into large blocks } \\
\text { which form extensive talus slopes. } \\
\text { and unpublished data of L. S, Gardner }\end{array}$ \\
\hline
\end{tabular}


Jurassic system

Nugget sandstone. - - The base of the Nugget sandstone is not exposed in the mapped area, but the formation is probably about 1,000 feet thick. It consists of fine-grained, white to pink or red sandstone and quartzite, generally thin bedded, though locally cross-bedded. The entire formation is highly resistant and weathers to blocks which cover extensive talus slopes.

Twin Creek limestone, - - Lying with apparent conformity on the Nugget sandstone, the Twin Creek limestone forms a unit 970 to 1,200 feet thick that is easily recognizable by its lithology. The Twin Creek consists chiefly of gray impure limestone that weathers into yellowish. gray splintery fragments or flakes of characteristic appearance. The formation forms rounded, gentle slopes with sparse vegetation.

Preuss formation. - - The Preuss formation is probably about 425 feet thick and separated from the Twin Creek limestone by a minor unconformity. The Preuss consists of interbedded shale, sandstone, and limestone ranging in color from red and green to brown and gray. The difficulty in disting uishing this formation from the overlying Stump and Ephraim formations made it necessary to map all three formations as a single unit.

Stump formation. - No distinctive lithologic contact separates the Stump formation from the underlying Preuss formation. The Stump is probably about 220 feet thick and consists chiefly of fine - to coarse-grained 
gray sandstone which is commonly ripple-marked and weathers to yellowish or brownish gray colors.

\section{Cretaceous system}

Gannett group.--Five formations totaling 1,100 to 1,400 feet of strata at the base of the Cretaceous make up the Gannett group. They are, from oldest to youngest, the Ephraim formation, Peterson limestone, Bechler formation, Draney limestone, and Tygee formation. A striking cyclic repetition of units of similar lithology is represented by the Peterson and Draney limestone each of which is overlain by red shale and sandstone, the Bechler and Tygee formations.

Ephraim formation. --Conformably overlying the Stump formation and forming the basal unit of the Gannett group is the Ephraim formation, at least 360 feet thick. The Ephraim formation consists of interbedded red to gray sandstone, conglomerate, reddish limestone, and reddish shales. The difficulty in distinguishing the Ephraim from the two underlying formations made it necessary to map all three formations as a single unit.

Peterson limestone.--Lying conformably on the Ephraim formation, the Peterson limestone is about 50 to 100 feet thick and forms prominent ledges. The Peterson consists of gray massive fine-grained limestone, which weathers into characteristic whitish outcrops. The formation makes an excellent horizon marker.

Bechler formation. - The Bechler formation lies conformably over the Peterson limestone and is at least 225 feet thick. The Bechler 
consists of red shale, which weathers into a red soil and forms a valley or saddle between the underlying and overlying limestone formations.

Draney limestone.-Conformably overlying the Bechler formation is the Draney limestone, about 175 feet thick. The weathered appear ance of the Draney limestone is very similar to that of the Peterson limestone and where not seen in continuous sequence is sometimes indistinguishable from the Peterson limestone. The Draney consists chiefly of gray massive fine-grained limestone with coarse-grained fossiliferous dark-colored limestone at the top. The limestone weathers into whitish outcrops that stand out as ridges between the enclosing red shales and sandstones.

Tygee formation. --Lying with apparent conformity on the underlying Draney limestone is the Tygee formation, 285 feet thick where measured on Skyline Ridge. The formation consists of interbedded red shale and gray to brown sandstone. The sandstone is commonly medium-grained, cross-bedded and friable, similar to sandstone beds in the Wayan.

The following section of the Tygee formation was measured on Skyline Ridge in sec. 27, T. 1 S., R. 42 E. The strata in this section are overturned and dip $85^{\circ}$ to the northeast. The intense deformation may have caused the formation to be thinner here than in a normal section. The section differs greatly from that of Kirkham (1924, p. 26-28) who included beds in the Tygee that are here called the Bear River formation. Apparently Kirkham measured his section east of the Fall 
Creek Ranger Station where faulting has duplicated the strata.

Section of the Tygee formation, sec. 27, T. 1 S., R. 42 E., Bonneville County, Idaho

The dip is about $85^{\circ}$ to the northeast, overturned.

Thickness

(feet)

Bear River formation:

Shale and siltstone, dark gray, ferruginous Not measured

Tygee formation:

Unit 1. Covered, red soil

2. Sandstone, fine-grained, dark gray to brown, hard

1.7

3. Covered, red soil

18

4. Sandstone, fine-grained, gray, hard 2

5. Covered, red soil 10.5

6. Sandstone, fine-grained, gray, hard, calcareous .8

7. Covered, red soil, probably red shale 52

8. Covered, dark soil, sandstone float 24

9. Sandstone, fine-to medium-grained, gray, cross-bedded, friable, calcareous; similar to sandstone beds in the Wayan formation

10. Covered, red soil, probably red shale 54

11. Sandstone, reddish-brown, calcareous 2

12. Covered, reddish॰brown soil 35

13. Sandstone, fine-grained, gray, numerous black grains, calcareous 2

14. Covered, reddish-gray soil and a thin ledge of gray siltstone

15. Sandstone, fine-grained, gray, massive, calcareous

16. Covered, reddish-gray soil

26

2

5

2

6

17. Sandstone, fine-grained, gray, massive, calcareous

18. Covered, light gray soil

19. Sand stone, fine-grained, brown, thin-bedded, calcareous

20. Covered, light-gray soil, limestone float

Total Tygee formation

$\frac{10}{285}$

Draney limestone:

Limestone, dark bluish-gray, fossiliferous Not measured 
Bear River formation.--The Bear River formation, lying with apparent conformity on the Tygee formation, is about 300 to 500 feet thick. The upper and lower contacts of the formation as described herein follow the usage of Louis S. Gardner (personal communication). The lower two-thirds of the formation consists of dark-gray, ferruginous, carbonaceous shale and siltstone interbedded with thin beds of dark brown sandstone. The upper third of the formation consists of a prominent ledge of medium-grained gray to brown quartzite or sandstone 75 feet thick, overlain by black shale, thin beds of fine-grained brown sandstone, coaly shale, and black fossiliferous granular lime。 stone of probable brackish water origin. The limestone and coaly shale are the uraniferous strata in the Fall Creek area. The Bear River formation does not contain any red or green shales that are so characteristic of nearly all the other Jurassic and Cretaceous clastic sediments in this area. The thick ledge-forming quartzite or sandstone in the upper third of the formation is the principal marker bed in this part of the section. The dark somber color of soils derived from the formation as a whole is fairly characteristic and helps to identify the formation where exposures are poor. The Bear River formation is generally poorly exposed and the outcrops are commonly complicated by faulting or folding so that no complete section of the formation was measured. The following section of the lower part of the formation was measured near the divide between Blacktail, Porcupine, and Pritchard Creeks. 
Section of the lower part of the Bear River formation in sec. 22, T. 1 N. , R. 42 E., Bonneville County, Idaho

The strata here dip 40 to $45^{\circ}$ to the northeast.

Bear River formation:

Thickness

(feet)

The upper part of the formation is not exposed.

Unit 1. Quartzite, fine-grained, brown, thin-bedded to massive, non-calcareous 22

2. Covered, quartzite float

3. Sandstone, fine-grained, gray, thin-bedded to massive, calcareous, weathers brown

4. Covered, dark-gray soil covered with small chips of dark-gray to brown siltstone float

5. Sand stone, fine-grained, quartzitic, darkbrown, ferruginous

6. Covered, dark-gray soil covered with small chips of dark-gray to brown siltstone float

Thickness, lower part of Bear River fm.

300

Tygee formation:

Covered, red soil

Not measured

A section of the upper part of the Bear River formation and part of the lower Wayan formation is described later in the section titled the Fall Creek coal prospect, page 25.

Wayan formation. - An unconformity probably separates the Wayan formation from the underlying Bear River, though proof of its existence depends primarily on the variation in the interval between the massive ledge of quartzite in the Bear River and the first appearance of red shale above the quartzite. The variation in the interval may also be dependent on primary depositional differences and unequal deformation at the time 
of folding. The formation is estimated to be at least 3,000 to 4,000 feet thick but the top of the formation is not exposed. No attempt was made to measure a stratigraphic section of the Wayan formation, but various exposures of it consist chiefly of red and purple shale interbedded with medium - to coarse-grained gray, cross-bedded, friable sandstone in beds up to 20 or 30 feet thick. The sandstone beds commonly form prominent ledges in the otherwise non-resistant strata. A characteristic of the sandstone beds is cross-bedding: this feature is very useful in determining the sequence of strata and therefore the structure, particularly in areas where folds are overturned.

\section{Igneous rocks}

Tertiary volcanic flows and tuffs lie unconformably on the folded and faulted strata of Mesozoic and Paleozoic age in the Caribou Mountains. Several hills within the mapped area are capped by remnants of volcanic rocks. The se remnants occur at different altitudes. Large remnants in the northern part of the area, secs. 20,29 , and $30, T .1$ N., R. 42 E., lie at altitudes ranging from 7,000 to 7,600 feet; whereas, similar remnants in the southwestern part of the area, secs, 29,30 , and 31, T. 1 S., R. 42 E. lie at about 6,600 to 6,700 feet. This difference in altitude would seem to indicate at least 1,000 feet of topographic relief at the time the volcanic rocks were deposited and may indicate that the original thickness of tuffs and flows was much greater than is represented in any of the present remnants. Ross and Forester (1947) 
assign the tuffs and flows to the oldest of a series of three volcanic groups recognized in southeastern Idaho. This oldest group consists of Miocene and Pliocene silicic volcanic rocks (welded tuffs and flows of rhyolitic appearance/ associated with the Snake River basalt. In the Fall Creek area this group of volcanic rocks are hard, dense, gray and tan to red, felsite-porphyries containing small feldspar phenocrysts. Black and gray obsidian with microlites and spherulites are also present.

\section{Structural setting}

The Caribou Mountains in southeastern Idaho are at the northern end of a system of parallel mountain ranges that form an arcuate belt along the Idaho-Wyoming border. The Caribou Mountains are characterized by complex structural features that trend northwest and ultimately plunge beneath the lavas of the Snake River Plain, which surrounds the northern end of the range. Closely spaced, parallel folds, overturned at many places and broken by faults, are the principal structural features of the range.

Cross section $A-A^{\prime}$ (fig. 2) shows the principal structural features in the area mapped. Folds in the southwestern part of the area are overturned to the northeast, whereas, folds in the northeastern part of the area are overturned towards the southwest. The Fall Creek coal prospect is located on the flank of a nearly symmetrical anticline between the two areas of overturning. Both longitudinal and transverse faults are superimposed on the pattern of the folds. Most of the longitudinal 
faults are normal faults but the faults along Skyline Ridge and the next ridge to the southwest are thrust faults. In sec. $12, \mathrm{~T}, 1 \mathrm{~S}, \mathrm{R}, 42 \mathrm{E}$. a longitudinal normal fault is offset by a transverse normal fault. At this place the relation between two types of faulting can be clearly deter mined. A northeast-trending joint pattern at right angles to the folding is prominent in the Fall Creek Basin and, with the transverse faults, seems to be an important factor in controlling the trellis-like drainage pattern so characteristic of the area.

Folding in the area ranges from minor drag folds to folds involving thousands of feet of strata where the horizontal distance from the axis of one fold is several miles from the axis of an adjacent fold.

Structural and geographic distribution of the Bear River formation

The Bear River formation is exposed along the flanks of many of the synclines and anticlines not only in the area mapped but also in much of the surrounding area. The prominent synclinal area at the northeastern corner of the area mapped (fig. 2) is divided into two synclines by a small faulted anticline. The Bear River formation occurs along the flanks of both the major and the minor folds, but exposures of the coal. bearing zone are very poor. Along the overturned southwest flank of the major anticlinal structure east of the Fall Creek Ranger Station the Bear River formation is duplicated by faulting. Exposures of the coalbearing zone are poor, and the zone itself is thin, apparently due to stretching which accompanied the intense deformation. A faulted 
anticline broken by transverse faults to form a hoxst-like structure brings the Bear River formation to the surface at the Fall Creek coal prospect. Elsewhere along the strike of the same anticlinal feature the zone of radioactive rocks is not exposed.

The Fall Creek Basin is a broad area of gentle relief eroded from folded strata in the Wayan formation. Between the Fall Creek coal prospect and Skyline Ridge an anticline overturned to the northeast has exposed strata older than the Wayan formation. However, the northeast flank of this anticline is so steep, the strata so thin, and the exposures so poor that the radioactive zone could not be found. The southwest flank of the anticline, however, has a relatively gentle dip and the coalbearing zone appears to be quite similar to that at the Fall Creek coal prospect, though the exposures are poor. Southwest of this overturned anticline is a thrust sheet that parallels the crest of Skyline Ridge. A belt of very complex structure lincluding recumbent folds and imbricate thrust sheets occurs between Skyline Ridge and Hell Creek. Within this belt of complex structure the Bear River formation is repeated at least three times, but the exposures of the coal-bearing zone are very poor. The intense deformation has probably caused the thinning of incompetent strata including the coal-bearing strata.

A relatively gentle syncline and anticline occupy the southwest corner of the area mapped, but soil and vegetation apparently cover the coal-bearing zone as no outcrops could be found. An area near the heads of Camp, Haskin, Trap, and Beaver Creeks, in the south central part 
of the mapped area, is one of complex and indeterminate structure. Soil cover, heavy vegetation, and hillwash mask the exposures. Locally, outcrops of the Bear River formation were recognized, but the structur al setting is poorly understood.

\section{URANIUM OCCURRENCES}

\section{General distribution}

Uranium-bearing coal and associated rocks were discovered in September 1951 at the entrance to the Fall Creek coal prospect, sec. 4, T. is., R. 42 E. (fig. 2). The uranium-bearing rocks are chiefly confined to a single stratigraphic zone in the upper part of the Bear River formation which occurs throughout much of the northern part of the Caribou Mountains. Limestone pebble conglomerates containing as much as 0.01 percent uranium were also found locally in the Wayan formation. One of these yielded a fossil bone fragment that contains 0.17 percent uranium. The Phosphoria formation of Permian age also contains uranium but a study of this formation in the Caribou Mountains was not included in this investigation.

The exposure of uranium-bearing strata in the Fall Creek coal prospect (locality 13, fig. 2 ) is presented in the next section. Elsewhere exposures of the uranium-bearing strata are rare. Trenches (localities 9, 10, 11 and 12, fig. 2 and table $A$, appendix) were dug to expose these strata at intervals along the strike northwest of the coal prospect 
for nearly half a mile. Together these five exposures supply the best information available on the lithology and uranium content of the uranium-bearing strata. Exposures elsewhere serve chiefly to demonstrate the widespread distribution of uranium-bearing strata. The locations of the exposures discussed below are shown on figure 1. Roadcuts have exposed uraniferous strata at locality 36 (sec. 18, T. 2 S., R. 45 E) and locality 38 (sec. 23, T. 3 S., R. 43 E.), both outside the area mapped and about 17 to 18 miles from the Fall Creek coal prospect. A select grab sample of coal from the dump of the Croley coal prospect, locality 37 (sec. 27, T. 1 S., R. 41 E.) contains 0.007 percent uranium in the coal and 0.03 percent uranium in the ash. The mine itself is not accessible and so the thickness and nature of the strata are not known. Coal on the dump of a mine in sec. 5, T. 32 N., R. 119 W. near Auburn, Wyo., 47 miles to the southeast (locality 41 ) contains 0.0035 percent uranium in the coal and 0.0053 percent uranium in the ash. Elsewhere low radioactivity was detected on the dumps of abandoned coal prospects including the Brinson prospect, locality 1 (sec. 34, T. 2 N., R. 40 E.). the Pine Creek Pass prospect, locality 4-(sec. 25, T. 3 N., R. 44 E.), which is 21 miles distant and at a mine in the Bear River formation about 12 miles west of Driggs (locality 5). However, the radioactivity detected in these areas amounted to 0.003 percent equivalent uranium or less. At several other localities radioactivity was detected in trenches, auger holes, or from limestone float, but fresh samples of the zone of coaly shale were not obtainable and the analyses of the se samples can serve 
only in a qualitative way to show the general distribution of uranium. (See figs. 1 and 2 , and table A, appendix.)

Fall Creek coal prospect

The Fall Creek coal prospect is an inclined shaft that extends about 83 feet down the dip of a bed of coaly shale in the Bear River formation. The prospect was dug about 1922 by J. H. Smith of Rigby, Idaho. He reports that he mined down the dip of the bed for a distance of about 98 feet and ceased operations when he reached water. A firm limestone roof and good timbering have helped to preserve the opening, though the floor is covered with rubble and the lower fifteen feet are filled with rubble. Figure $3 \mathrm{~A}$ is a diagrammatic longitudinal section of the inclined shaft.

The prospect lies on the northeast flank of a fanl:ad aniclime (iry $=2)$. The beds here dip 33 degrees northeast and strike northwost. A fault system transverse to the general strike has uplifted the Baar River formation for about half a mile along the axis of the anticline. The inclined shaft has been driven in a zone of incompetent strata which have been sheared by differential movement and are characterized by drag folds.

Uranium in detectable amounts at the Fall Creek coal prospect is confined to a stratigraphic zone of brackish or fresh water organic-rich strata, units 16 through 21 in the stratigraphic section as described below and represented graphically in figure 4 . 
26

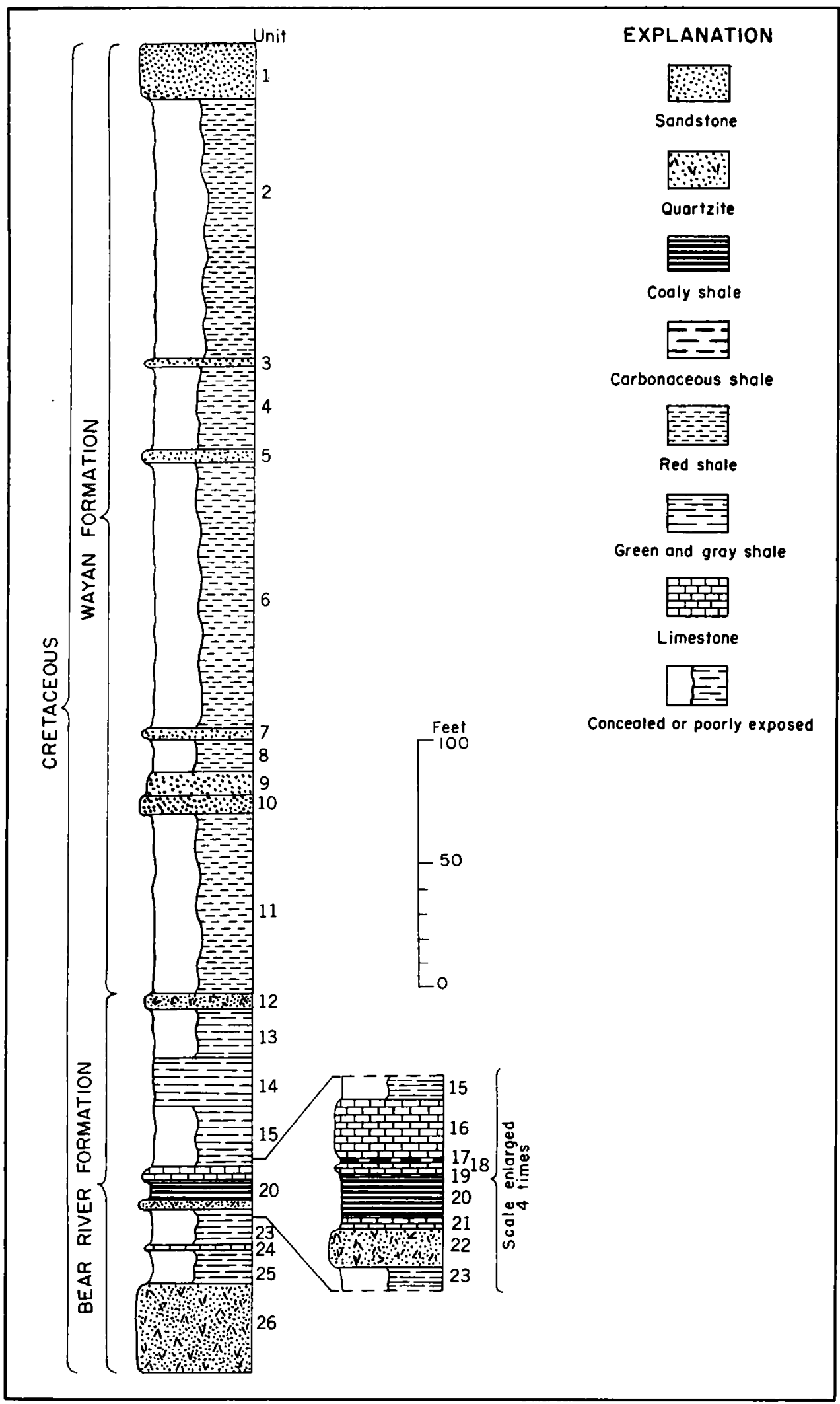

FIGURE 4.--STRATIGRAPHIIC SECTION OF THE UPPER PART OF THE BEAR RIVER FORMATION AND THE LOWER PART OF THE WAYAN FORMATION AS MEASURED AT THE FALL CREEK COAL PROSPECT 
Stratigraphic section of the upper part of the Bear River formation and the lower part of the Wayan formation, measured at the Fall Creek coal prospect in sec. 4, T. 1 S., R. 42 E., Bonneville County, Idaho.

The dip here is about 30 to $35^{\circ}$ to the northeast.

Wayan formation:

Thickness

(feet) (in.)

Upper part of the Wayan formation not measured

Unit 1. Sandstone, light-gray, medium-grained, thinto thick-bedded, cross-bedded; forms prominent ledge

2. Covered; probably contains red shale; forms slope

106

3. Sandstone, bluish-gray, fine - to mediumgrained

4. Covered; probably contains red shale; forms slope

5. Sandstone, bluish-gray, fine-grained

6. Covered; probably contains red shale; forms slope

108

7. Sandstone, greenish-gray, fine-grained

8. Covered; probably contains red shale; forms slope

9. Sandstone, light gray, fine-to medium-grained, forms ledge locally

10.

10. Sandstone, light gray, fine-to medium-grained, cross-bedded, thin-bedded, slightly friable; forms ledge; the lower $6-8$ inches contain a siltstone-pebble conglomerate

11. Covered with reddish soil; probably red shale, forms slope

Total Wayan formation (measured)

$\frac{75}{386}$

Bear River formation:

Unit 12. Quartzite, greenish-gray, fine-grained to dense 6

13. Covered; probably shale, green, not fissile

14. Shale, greenish- to purplish-gray, not fissile; forms slope

15. Covered by road fill; probably shale, green, not fissile 
Bear River formation:--Continued

Unit 16. Limestone, carbonaceous, gray to black, weathers gray, dense to finely crystalline, contains fossil fragments including smooth gastropod shells, uraniferous

Thickness

(feet) (in.)

17. Shale, carbonaceous, dark greenish-gray,

17. Shale, carbonaceous, dark greenish-gray,
uraniferous

4

18. Limestone, carbonaceous, dark gray to black, weathers gray: contains fossil fragments;

fresh fragments give off fetid odor; uraniferous

1

19. Shale gouge, carbonaceous, contains lenses of clay, coal, and limestone: uraniferous

20. Coaly shale and thin lenses of coal, clay and limestone; sheared. This unit contains the highest percent of uranium

21. Shale, carbonaceous: limestone, carbonaceous; and coal, uraniferous

22. Quartzite, greenish-gray to brown, fine grained; forms ledge

23. Mostly covered slope-forming unit: probably gray to black, fissile shale

24. Limestone, impure, dark-brown, weathers brown, dense to finely crystalline; fresh fragments give off a fetid odox; contains fossil fragments including smooth gastropod shells

25. Mostly covered, slope-forming unit; probably gray to black, fissile shale

26. Quartzite, greenish gray to brown, fine-grained; cross-bedded in part; forms massive ledge, the most prominent marker bed in this part of the section. The lower part of the Bear River formation is not exposed Total Bear River formation exposed (measured) $\frac{35}{152}$

Units 16, 17, and 18 in the above section may be considered as a relatively resistant limestone zone with a thin shale parting. The limestone ranges in lithology from a gray, fine-grained limestone that is nonuraniferous to a black medium - to coarse-grained limestone rich in 
carbonaceous material, mascerated fossil fragments, and some gastropod and pelecypod shells. This type of limestone rich in organic mater ial is commonly, though not invariably, uranium-bearing throughout a widespread area. The roof of the Fall Creek coal prospect is formed by the base of this limestone. It has a wavy lower surface and contains cavernous joints which may have been enlarged by groundwater circulation. A group of incompetent strata underlying the limestone have been sheared by differential movement and are characterized by shear structure rather than bedding features.

Unit 19 in the stratigraphic section at the Fall Creek prospect is a gouge zone of variable thickness and lithology in which the shear structure is roughly parallel to the bedding of the overlying limestone units. This unit is composed of varying proportions of carbonaceous shale, carbonaceous and calcareous clay gouge, thin limestone lenses, and thin lenses of coal. A sample of black vitreous coal from a 2-inch thick lens was insoluble in carbon disulfide. Pyrite occurs in the lenses of coal. The unit ranges in thickness from 4 inches to 2 feet and contains an average of about 0.02 percent uranium.

Unit 20, the most highly uranifexous unit of the group, consists of sheared coaly shale with thin lenses of coal, clay, and limestone; it is approximately 4 feet thick. Unit 20 is characterized by drag folds in which lenses of yellow and gray clay, coal, and limestone have been dragged into the sheared coaly shale. Gypsum, calcite, and jarosite commonly occur as secondary encrustations on fractures, joints, and 
shear planes. A bulk sample of unit 20 was collected about 35 feet from the entrance to the inclined shaft for routine U. S. Bureau of Mines coal analysis. The regults are shown in table 2, along with the analysis of a sample collected in 1923 from the same or a nearby prospect. The ash content of this bulk sample is too high for commercial use of the material as coal. However, sufficient carbonaceous matter is present to make the material comparable to coal. The ratio of carbon to hydrogen is similar to that of subbituminous coal, but the ratio of volatile matter to fixed carbon is higher than for most coals except certain unusual varieties such as cannel coal. This high proportion of volatile matter indicates that this unit may originally have been similar to canneloid shale rather than a true coal. The top foot of unit 20 contains an average of about 0.04 percent uranium and a maximum of about 0.13 percent uranium. The bottom 3 feet contain an average of about 0.01 percent uranium. Underlying the coaly shale of unit 20 is unit 21 , which like unit 19 consists of carbonaceous shale, with lenses of limestone, clay, and jet black coal. The shear planes in this unit are wavy but roughly parallel the bedding. The unit ranges in thickness from about 6 inches to 2 feet; the base is poorly exposed. The uranium content of this unit is relatively low and averages slightly less than 0.006 percent.

The lowest ash content of samples collected in the Fall Creek coal prospect was 17.3 percent in sample VI-364, a jet black vitreous coal from a small lens, and 43.7 percent in sample VI-413, a 15 -inch channel sample of the zone of sheared coaly shale. These and other samples 
Table 2. $-\infty$ U, S, Bureau of Mines coal a nalyses of samples from the Fall Creek coal prospect

PROXI MATE ANALYSIS ULTDMATE ANALYSIS FUSIBIIITY

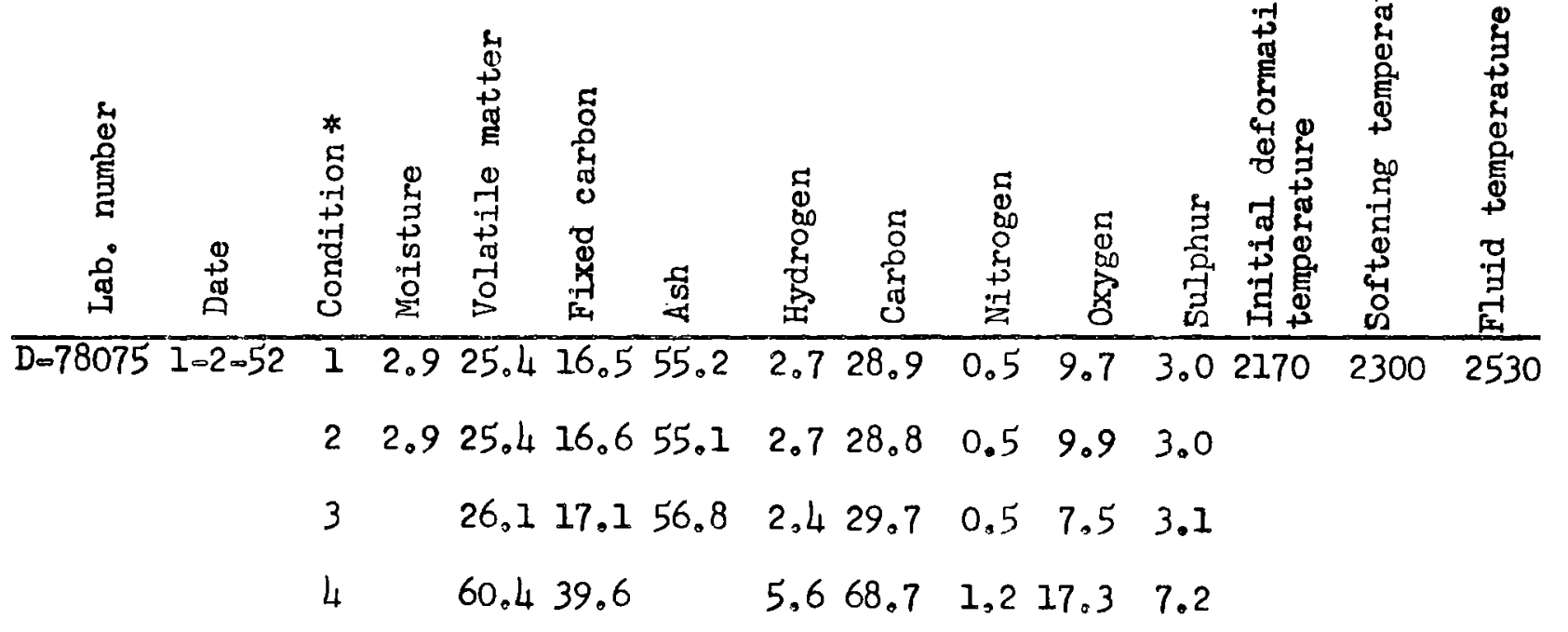

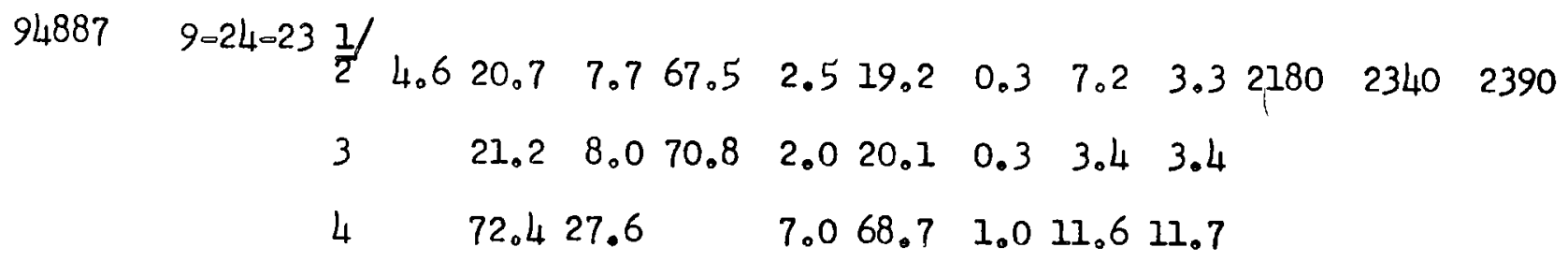

* Conditions

1. Air dried

2. As received

3. Moisture free

4. Moisture and ash free

1/ (Cooper, $\mathrm{H}_{0} \mathrm{M}_{\circ}$, and others, 1947) 
relatively low in ash contained considerably more uranium than most samples with higher ash contents. At localities 9 (fig. 2) and 37 (fig. 1), grab samples VI-371 and VI-1140 from abandoned prospect dumps had relatively low ash contents of 37 and 22 percent and uranium contents of 0.08 and 0.007 percent, respectively.

\section{DISTRIBUTION OF URANIUM AND OTHER MINOR ELEMENTS IN}

\section{CARBONACEOUS MATERIAL}

Coal is a complex mixture of organic and inorganic compounds and characteristically contains a large suite of minor elements in trace quantities. The ash of coal that has burned represents a concentration of those elements which are non-combustible and non-volatile, though not necessarily in the same form as originally present. The elements present in the ash include at least two and probably three distinct suites according to their mode of origin (Katchenkov, 1952). The extraneous ash is generally the most abundant and includes several of the common rockforming elements which have been carried into the coal from the exterior in the form of sand and clay. The extraneous ash probably includes such elements as $\mathrm{Si}, \mathrm{Al}, \mathrm{Ca}, \mathrm{Fe}$, and $\mathrm{Mg}$, and possibly also $\mathrm{Na}, \mathrm{K}, \mathrm{Mn}$, and $\mathrm{Ti}$, most of which are likely to be abundant in those coals having a high ash content. The intrinsic ash consists of those elements that were part of the mineral constituents in the plant bodies from which the coal was formed. These elements generally include several of the common metals, 
such as $\mathrm{Pb}, \mathrm{Ni}, \mathrm{Zn}$, and $\mathrm{Co}-\mathrm{present}$ commonly only in trace amounts, plus many minor metals such as $\mathrm{Be}, \mathrm{Sc}, \mathrm{Ga}, \mathrm{Ge}, \mathrm{Y}, \mathrm{Mo}, \mathrm{Ag}, \mathrm{Sn}, \mathrm{Tl}$, and $\mathrm{Bi}$-- also present only in trace amounts. Several additional elements including sulphur, phosphorus, and boron are common constituents of raw coal but may or may not be present in the ash depending on the original form of the element present in coal. Elements not normally abun. dant in plant tissues or common rock minerals are sometimes found in considerable abundance in coal ash. Germanium one such element, and it has been pointed out by Haught (1954) that such an accumulation is difficult to explain except as the result of secondary enrichment. Thus, secondary enrichment forms the third possible distinct suite of elements that may occur in coal. Any specific element may be introduced by any one or a combination of the three methods.

Until recently uranium was not considered to be important as a trace element in coal because it is normally present only in extremely small amounts, probably in the $r$ ange of $0.000 X$ percent or less. Rankama and Sahama (1950, p. 637) quote a figure of 0.0000005 percent uranium for the content of coal ash. It is now known, however, that the ash of coal can contain as much as 1 percent uranium (Vine and others, 1953). The nature of the occurrence of uranium in coal is not clearly understood. Inve stigations by Tolmachev (1943) suggest that uranium may be associated with carbonaceous material in the form of an adsorbed ion held by the platy structure of the carbon molecules. Ion exchange studies by Breger and Deul (1952) suggest that uranium may occur as a metallo- 
organic compound in lignite from South Dakota. Autoradiographic studies by Koppe and others (1954) suggest that uranium or one of its radioactive daughter products is concentrated in an unidentified crystalline material that forms the pore filling of fossil cell lumens in coal. No uranium minerals have been recognized in the carbonaceous material of the Fall Creek area, though an autoradiograph made by exposing ortho-type film for three weeks to a cut section of coal, sample VI-364, shows numerous point sources of radiation in a clouded background and indicates a concentration of radioactive material in microscopic units within a mass of less intense dìsseminated radioactive substance.

Semiquantitative spectrographic analyses were obtained on a select group of carbonaceous rock samples from the Fall Creek area. The analyses of samples in table $G$, appendix, are arranged by lithologic types, as follows: coal, less than 50 percent ash; coaly shale, from 50 to 80 percent ash; carbonaceous shale, more than 80 percent ash; and limestone, for which an ash determination is not significant. Within each group the samples are arranged in order of decreasing percent uranium in the ash. With two minor exceptions in the coal group this results in the entire listing being in order of decreasing percent uranium in the ash. In other words, the percent uranium in the ash is nearly inversely proportional to the percent ash in the sample.

The essential rock-forming elements are listed at the left and the accessory elements are grouped to the right according to chemical affinities. Most of the elements occur in what may be considered 
normal quantity (Goldschmidt, 1937, p. 669), but there are several which deviate from the normal. Uranium, of course, has a range of approximately 50 to one, and even the sample with the least uranium probably contains on the order of 10 times that normally found in rocks of this type. Molybdenum and germanium correlate remarkably well with the uranium (fig. 5), for the samples which are high in uranium also contain one or two orders of magnitude times the normal quantity of molybdenum and germanium, although the germanium and molybdenum contents are not consistently proportional to the uranium content. This correlation of the three elements, which is apparent in the highuranium samples and less apparent in the low-grade uranium samples, suggests a geochemical relation and possibly a common origin. Several elements including $\mathrm{Be}, \mathrm{Zn}, \mathrm{Ga}, \mathrm{Y}$, and $\mathrm{Pb}$ appear to be less abundant in the Fall Creek material than in average coal though the significance of this fact is not apparent.

Uranium in the carbonaceous rocks of the Fall Creek area occurs most abundantly in the units that contain the most carbonaceous material (fig. 3). These units include coal, coaly shale, carbonaceous shale, and black carbonaceous limestone in a general decreasing order of uranium content. However, even within each unit the uranium content is far from uniform. This is perhaps best shown within the unit of sheared coaly shale because of the greater number of samples collected. Within this unit the uranium content varies from 0.004 (sample VI-384) 


\section{EXPLANATION}

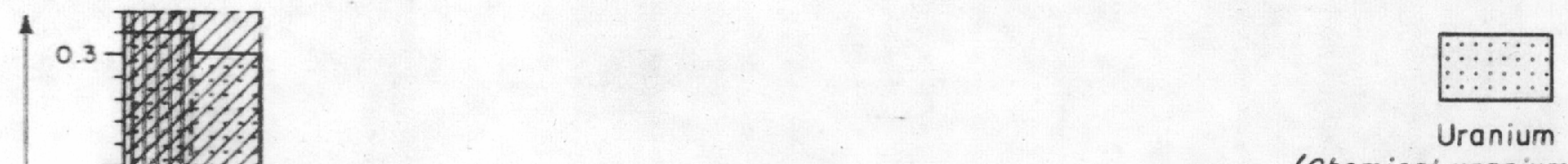

(Chemical uranium in ash)

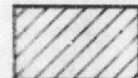

Moiybdenum

(Semi-quantitative spectrographic analysis)

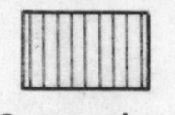

Germanium

(Semi-quantitative spectrographic analysis)

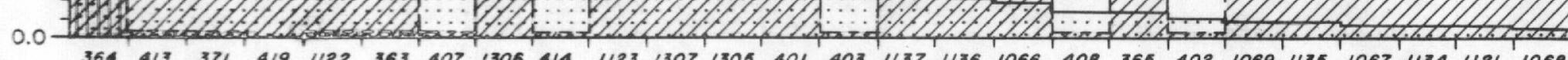

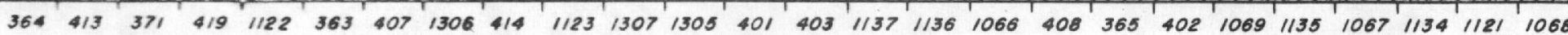

Field sample numbers. Samples arranged in order of decreasing percent uranium in ash.

FIGURE 5.-- COMPARISON OF URANIUM, MOLYBDENUM, AND GERMANIUM CONTENT IN THE ASH OF COAL 
to 0.131 (sample VI-413). In general, the uranium content is low near the weathered surface exposure and increages to a maximum at about 60 feet down the dip of the bed. The weighted-average content of samples from this unit at the entrance to the inclined shaft is 0.015 percent uranium, whereas, the weighted average for the same unit 60 feet from the entrance is 0.043 percent uranium. There is also a pronounced vertical pattern to the distribution of uranium. The top 1 -foot of this coaly shale unit contains an average of about 0.044 percent uranium, which compares with only about 0.008 percent uranium contained in the bottom 1 - foot of the unit.

\section{ORIGIN OF THE URANIUM OCCURRENCES}

Attention was first focused on the occurrence of uranium in coal when Slaughter and Nelson (1946) discovered radioactive coal beds in the Wasatch formation of Eocene age in the Red Desert area, Sweetwater County, Wyo., not far from the occurrence of schroeckingerite in the Lost Creek area. In 1948 Wyant and Beroni (1950) discovered radioactive lignite in the Fort Union formation of Paleocene age in the western part of North Dakota. As a result of their preliminary investigations in 1948 and 1949 in North Dakota they suggested that the uranium was (1) fixed by the living organisms or dead organic matter from uraniferous surface waters at the same time that the carbonaceous material was accumulating in a coal bog, or (2) deposited with other detrital minerals in sediments overlying or marginal to the lignite 
and subsequently leached and carried to the lignite by migrating ground water solutions. Later, detailed mapping in 1949 of the Bullion Butte and Sentinel Butte areas of western North Dakota by Beroni and Bauer (1952) suggested that the uranium was syngenetic and derived from the leaching of volcanic ash beds within the Fort Union formation that are now represented by analcite and montmorillonite. In 1950, detailed mapping by Denson, Bachman and Zeller (1950) in the Slim Buttes area of South Dakota provided evidence that the uranium was introduced by downward percolating ground water solutions and they suggested that the uranium was leached from volcanic ash in the Oligocene and Miocene strata which overlay the uraniferous lignite. Thus, the uranium would be epigenetic in origin.

At the present time at least four general hypotheses for the origin of uranium in coal and carbonaceous materials should be considered. These may be classed according to the time and manner of emplacement of the contained uranium, as follows:

1. Syngenetic: Simultaneous emplacement of the uranium with the sedimentary material in which it occurs, such as fixation of the uranium by the living plants and organisms from the water in which they grew.

2. Diagenetic: Emplacement of the uranium after the deposition of the sediment and prior to the consolidation or deep burial of the sedimentary material, such as introduction of uranium-bearing waters during or shortly after the accumulation of the sedimentary material and chemical reaction with the dead organic material so as to remove 
the uranium from solution.

3. Epigenetic: Emplacement of the uranium long after the consolidation or deep burial of the sedimentary material, such as -

A. Invasion of carbonaceous uranium-bearing rocks by hydrothermal solutions and removal of uranium from solution by reaction with the organic material: or

B. Migration through carbonaceous rocks of uraniumbearing meteoric waters under the force of gravity and removal of the uranium from solution by reaction with the organic material.

In each category there is general agreement that the organic mate rial is in some way responsible for concentrating the uranium from a source which is relatively dilute. It is not known whether the organic material concentrates uranium by reduction, ionic adsorption, chemical combination with the organic constituents, or by other related processes.

It should be possible to interpret the manner of origin of the uranium from the gize and shape of the deposit, the distribution of uxanium within the deposit, and the type of gangue minerals which characterize the deposit. A syngenetic or diagenetic origin should produce a blanket deposit without structural control, and it should be relatively uniform and widespread, similar to the uraniferous black shale of the Chattanooga or of the black shales and phosphorite of the Phosphoria formation. A hydrothermal origin could be expected to form small local deposits of uranium concentrated near veins or fissures from which the solutions rose and 
these should be accompanied by gangue minerals and wall rock alteration characteristic of hydrothermal mineralization. On the other hand, an epigenetic origin by migrating meteoric watexs might produce large or small deposits depending on (1) the volume and content of available uranium of the source beds: (2) the various factors that influence the flow of groundwater from the source beds to the receptor beds such as the regional and local structure and the permeability of the rocks: and (3) variations in the organic content of the receptor rock. It could be accompanied by the type of gangue minerals which form during the normal processes of weathexĩng.

The limited data available on the Fall Creek deposit make it difo ficult to show which hypothesis is most plausible for the origin of the uranium here. Hydrothermal gold deposits have been found on Caribou Mountain, an igneous inteusion over 20 miles away, but there is no evidence of hydrothermal activity near the Fall Creek coal prospect. The presence of radioactivity in the Bear River formation over a widespread area is somewhat suggestive of a sygenetic or diagenetic origin of the uranium accumulations. However, the aranium content of samples from this wide opread area is far from being uniform and some of the samples from the Fall Creek coal prospect contain several times more uranium than that normally found in the Chattanooga or Phosphoria formations, which have been mentioned as examples of deposits of syngenetic origin. Also, there is an apparent relation between the grade of the deposit and structure. The top of the zone of sheared coaly shale 
contains the highest percent of uranium, and there is an apparent increase in the percent of uranium below prominent cavernous joints and fissures in the overlying bed of limestone. Where vertical strata were examined and sampled (localities 1 and 39) they were found to contain less uranium than elsewhere. These factors are difficult to explain by a syngenetic or diagenetic origin and are suggestive of an epigenetic oxigin of the uranium with the mineralizing solutions being introduced from above. More data are desirable before the structural control of the deposit can be established with certainty.

A definite structural control has been demonstrated in other areas of uraniferous coals and lignites where additional field relationships can be observed indicating an epigenetic origin by migrating meteoric waters. Denson, Bachman, and Zeller (1950) first observed that the uranium-beaxing lignites in western North and South Dakota were consis tently the stratigrapkically highest bed of lignite below the pre-Oligocene unconformity, whether the Iignite was in the Hell Creek formation of Cretaceous age or the Sentinel Butte member of the Fort Union formation of Paleocene age. The uranium content decreases sharply in succeeding lower beds of lignite. Structural control was also observed in the La Ventana area in Sandoval County, N. Mex. by Vine and others (1953) where uranium occurs in coal and carbonaceous shale in the Dakota formation and the Mesaverde group. There, uranium occurs in the topographically highest coal that was yery close to the base of tuffs of Pleistocene age that have been eroded away. Concentrations of 
uranium in minor structural features were explained by the introduction of uranium with percolating meteoric waters. Similarly, the relationship between uranium concentrations and structural features or permea. bility was observed by Masursky and Pipiringos (1953) in the Red Desert area of Wyoming and by Hail and Gill (1953) in the Croose Creek area of southern Idabo. Thus, from the Jimited evidence at the Fall Creek coal prospect and the comparison with other deposits of uraniferous coal and lignite, the epigenetic origin of the urantum from migrating meteoric water seems most plausible in the Fall Creek area.

There still remains the pxoblem of the altimate oxigin of the uranium which is transported to the deposit by meteoric water. In the Dakota uraniferous lignite area the utingate source is thought to be the Oligocene and Miocene tuffaceous sandstones of the White River and Arikaree formations (Denson, Bachman, and Zellex, 1950) which directly overlie the uraniferous lignite. In the La Ventana area, N. Mex., the ultimate source is believed to be the Bandeliex tuff of Pleistocene (?) age (Vine and othexs, 1953). In the Coose Creek area, Idaho, the source is be. lieved to be the Salt Lake thyolitic tuffs of Pliocene age which are interbedded with the lignite. In each example the ultimate source is believed to be a rock of volcanic origin, either a tuffaceous sandstone or a volcanic tuff containing uranium in a highly disseminated form.

A similar potential source for the uranium existed in the Fall Creek area. The entire area was once overlain by Miocene or Pliocene silicic volcanic rocks of which only a few small remnants remain as 
shown on the geologic map (fig. 2). Samples of the se rocks contain 0.002 to 0.004 percent equivalent uranium and 0.0012 percent uranium. Analyses of spring waters issuing from source rocks have helped to demonstrate the leaching action of groundwater in other areas. Some spring waters from the White River formation in South Dakota and Wyoming commonly contain 40 or more parts per billion of uranium. This compares with less than 2 parts per billion for most waters from nontuffaceous rocks that have been tested /Fix, P. F., oral communica tion). No springs could be found in the Fall Creek area issuing direct. ly from the silicic volcanic rocks, but wate $x$ from a spring at the Fall Creek Ranger Station, which is near the trough of a syncline, part of which is overlain by silicic volcanic rocks contained 8 parts uranium per billion.

The origin of the uranium is of considerable economic importance because of the influence that the mode of origin has on the approach to be used in physical exploration. If the epigenetic hypothesis is true, then exploration for ore grade material should be conducted in areas of structure favorable for the concentration and flow of groundwater solutions such as along synclinal troughs. On the other hand, if the origin is syngenetic or diagenetic then the deposit should be relatively uniform over a large area and exploration should be conducted in areas most easily mined. 


\section{RESULTS OF CORE DRILLING}

\section{Drilling ope rations}

Purpose

Core drilling in the Fall Creek area, Bonneville County, Idaho was planned to obtain subsurface information on the areal extent, thickness, and grade of unweathered uranium-bearing carbonaceous rocks on which an appraisal of the reseres of aranium might be based. It was hoped that additional information might also be obtained on the relation between uranium content and the structural position of the uraniferous strata.

\section{Areas drilled}

Core holes were drilled at three different structural settings (fig. 6) to obtain information on the reserves of uranium in three blocks, as

\section{follows:}

(a) Core holes 1 and 2 were drilled on the northeast limb of an anticline in the northern part of section $4, T$. 1 S., R. $42 \mathrm{E}$.

(b) Core holes 3, 4, and 4A were drilled on the southwest limb of an anticline near the center of the same section.

(c) Core hole 5 was drilled on the southwest limb of an anticline at the nor theast corner of section 8 , T. 1 S., R. 42 E.

All holes were planned to test the same stratigraphic zone exposed in the Fall Creek coal prospect. 


\section{R. 42 E.}

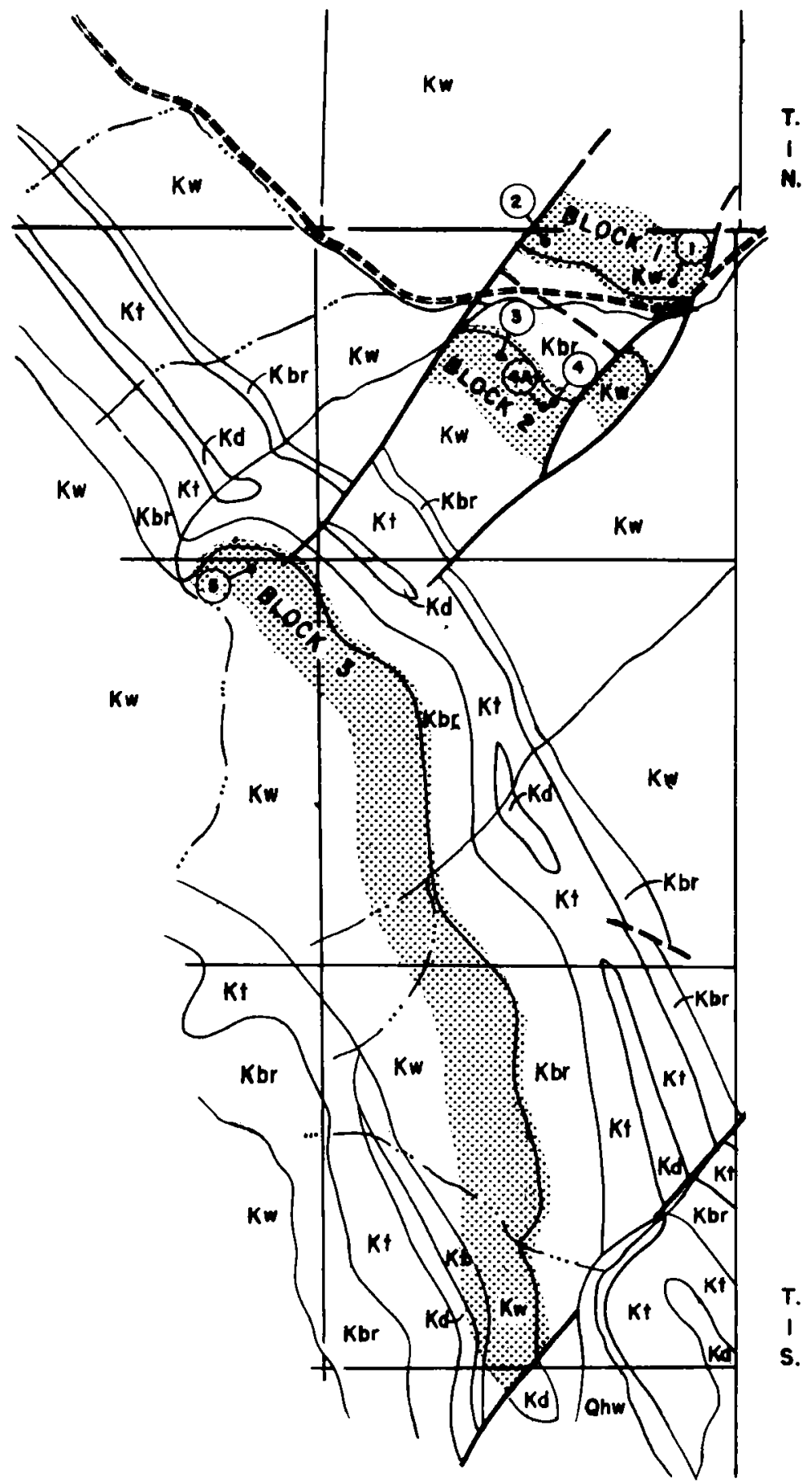

T.

M.

EXPLANATION

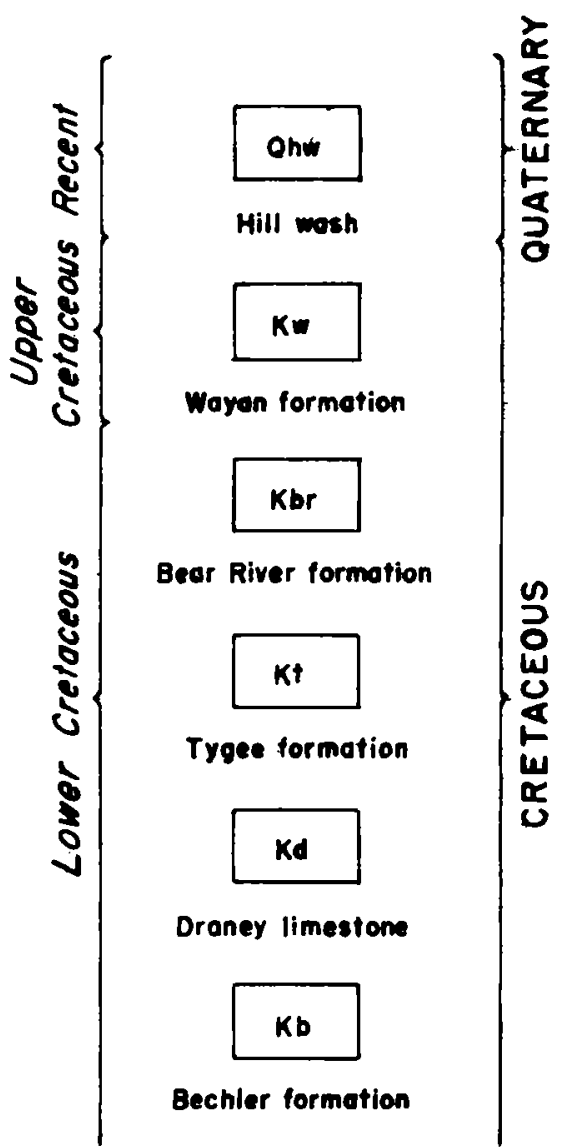

Area used in estimating resorves of uranium - bearing rocks

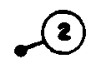

Core holes drilled

0 


\section{Drilling contract}

All drilling was done under contract no, 14-08-001-720, dated April 10, 1953 with the Boyles Bros. Drilling Company, Salt Lake City, Utah. Drilling began on June 6 and was completed on August 8, 1953. The work was performed under the direction of Max L. Troyer, project chief. The schedule of unit prices was as follows:

$$
\begin{aligned}
& \text { Surface to } 250 \text { feet (NX core . . . . . . \$5.90 per foot } \\
& \text { Surface to } 250 \text { feet (BX core). . . . . . 5.30 per foot } \\
& 250 \text { to } 500 \text { feet (NX core) . . . . . . } 7.90 \text { per foot } \\
& \text { Surface to } 250 \text { feet (solid bit) . . . . . . } 5.60 \text { per foot } \\
& \text { Reaming NX hole to } 31 / 2 \text { inches. . . . . } 2.50 \text { per foot } \\
& \text { Cementing . . . . . . . . . . . } 4.50 \text { per foot } \\
& \text { Delays caused by the government . . . . } 8.00 \text { per hour }
\end{aligned}
$$

The contract specified a minimum recovery of 80 percent while drilling in coal and carbonaceous shale. A total of 1,618 feet of drilling was completed at a cost of $\$ 12,020.00$

\section{Equipment}

The core drilling in the Fall Creek area was done with two truckmounted diamond drills equipped with hydraulic lifts. Each drill was operated one eight-hour shift six days a week. Cores were cut with $21 / 8$ inch $(N X)$ face discharge diamond bits on a 10 foot swivel-tube core barrel. Because of the difficulty in obtaining core recovery in the coaly 
shale zone the core barrel was hammered through the zone. This provided the desired recovery, but the sample was badly disturbed. In order to maintain circulation of the drilling fluid it was necessary to ream and set casing at most of the drill sites. From 7 to 280 feet of • casing (average about 90 feet) was used per drill site. Even so, the caving and frequent loss of circulation made it necessary to cement an average of 25 feet per hole. One 1,000-gallon water truck serviced the two drills; average hauling distance for the water truck was about a mile.

\section{Drilling progress}

It was originally estimated that one month would be sufficient time to complete the drilling, but nearly twice that much time was required due to delays caused by caving, loss of circulation, reaming, cementing, and redrilling. A combined total of 1,618 feet of drilling was completed in gix holes. (See figs. 6 and 7.) The average hole depth was 270 feet, the deepest being 472 and the shallowest 55 feet. Four hours was the average time for moving and setting up.

Core recovery of rocks other than the coaly shale was good, but core recovery of the coaly shale was poor.

The structure of the area was much more complex than anticipated and only one hole penetrated the expected thickness of radioactive carbonaceous rocks. Failure of the other holes to penetrate the objective was due to intersection with faults and steepening of the dip at depth. 


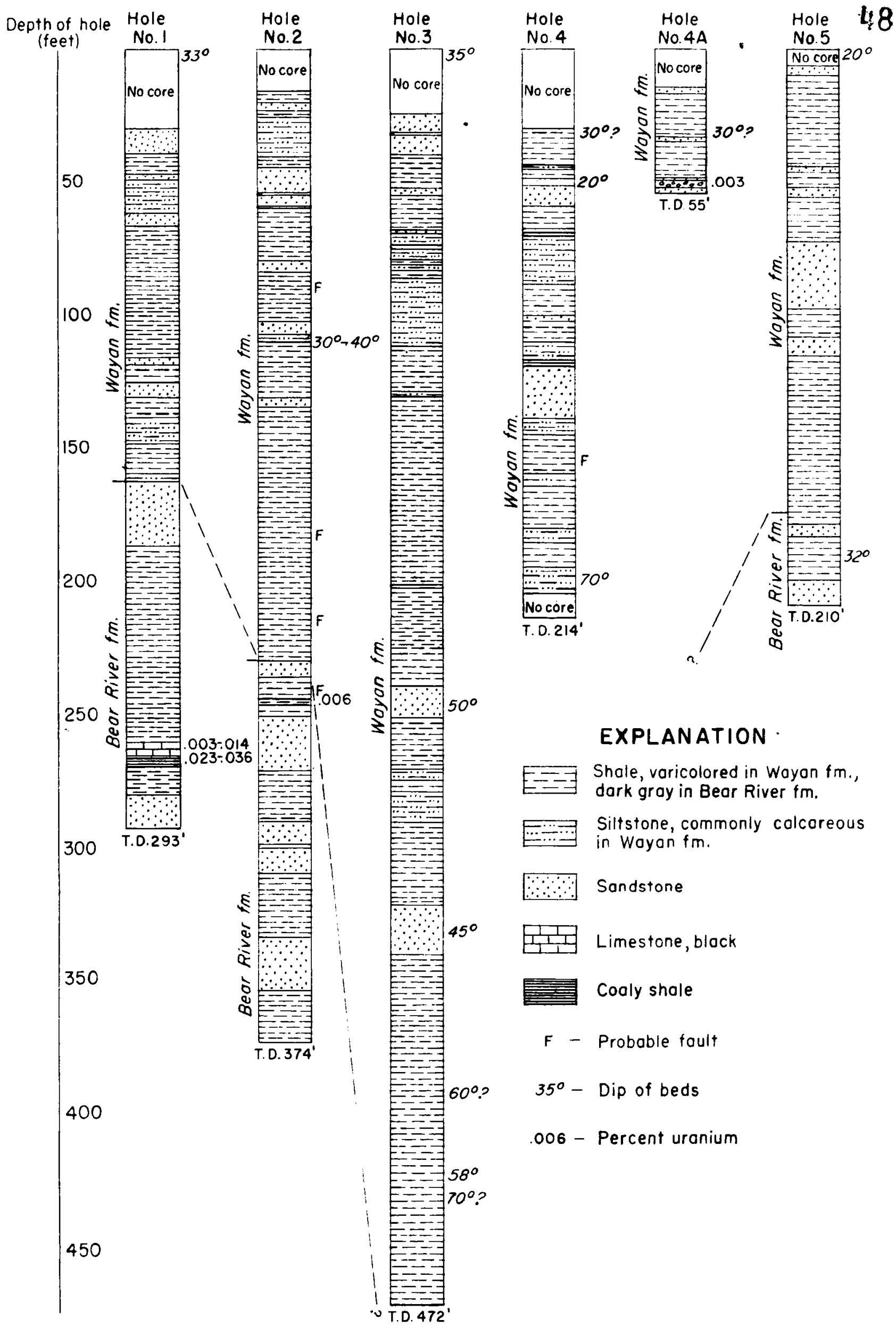


Description of core holes

Core hole 1 was drilled to a depth of 293 feet from a location about 300 feet northeast and 60 feet higher than the exposure of uranium-bearing rocks at the Fall Creek coal prospect. Uraniferous limestone and carbonaceous shale were penetrated from 264 to 270.9 feet. Analyses of 8 samples, VI-1300 to VI-13.07( table D, appendix), from this zone ranged from 0.003 to 0.036 percent uranium in the sample. The highest grade sample, VI-1306, contained 0.056 percent uranium in the ash and 7.0.0 percent ash. This is the only hole which penetrated the anticipated thickness of uranium-bearing rock.

Core hole 2 was drilled to a depth of 374 feet from a location about 350 feet northeast and 100 feet higher than the outcrop of uraniferous rock exposed at carbonaceous rock sample locality 9. If the surface dips of about 35 degrees had remained constant at depth, the uraniumbearing zone should have been penetrated at about 345 feet. However, a thin zone of dark gray carbonaceous shale from core depths of 246 to 248 feet analyzed 0.006 percent equivajent uranium (sample VI-1308). Below this zone the core more nearly resembles the carbonaceous, ferruginous siltstone present in the lower two-thirds of the Bear River formation. Therefore, if the thin zone from 246 to 248 feet represents the uranium-bearing zone exposed at the Fall Creek coal prospect, it has apparently been squeezed and deformed because of its proximity to a fault. 
Core hole 3 was drilled to a depth of 472 feet from a location about 430 feet southwest and at the same altitude as the outcrop of radioactive soil and limestone exposed at carbonaceous rock sample locality 14 . Based on the surface dip of about 35 degrees the uranium-bearing zone should have been penetrated at a depth of about 295 feet. However, the dip of the rocks as observed from the core gradually increased to as much as 70 degrees, and the red shales characteristic of the Wayan formation were encountered at the bottom of the hole. No reliable esti. mate can be made as to the depth required to penetrate the uraniferous zone in the Bear River formation.

Core hole 4 was drilled to a depth of 214 feet from a location 140 feet south and level with the outcrop of radioactive soil and limestone near carbonaceous rock sample locality 15. Dip readings at the surface in this area range from 20 to 45 degrees so the uranium-bearing zone should have been penetrated somewhere between 50 and 135 feet deepth. Radioactivity was encountered at a depth of between 53 and 54 feet, but no core was recovered, and no more radioactivity was encountered in the remainder of the hole which contained red shale, characteristic of the Wayan formation. Core from the bottom of the hole dips 70 degrees. Core hole $4 \mathrm{~A}$ was drilled to a depth of 55 feet from a location offset about 3 feet from core hole number 4 . The purpose of drilling core hole 4A was to obtain a sample of core from the radioactive zone from which no core was obtained in hole 4. At a depth of 51.5 to 52 feet a uraniumbearing limestone pebble conglomerate was cored similar to limestone 
pebble conglomerates observed in outcrops of the Wayan formation.

Core hole 5 was drilled to a depth of 210 feet from a location about 330 feet south and 42 feet below the outcrop of radioactive soil and limestone about half a mile northwest of carbonaceous rock sample locality 24. Dips at the surface near the hole are from 20 to 22 degrees so the uranium-bearing zone should have been penetrated at a depth somewhere between 75 and 90 feet. However, dips as high as $32^{\circ}$ were observed in the core. When the contract was terminated, the hole was completed in the Beax River formation, probably within 50 feet of the objective.

\section{INFERRED RESERVES}

Prior to the completion of the core drilling program the inferred reserves of uranium-bearing rock in the Fall Creek area were estimated at about 1,500 tons of uxanium in about seven million tons of rock (Vine, 1953, p. 23). This timate was based on the average thickness and grade observed in the Fall Creek coal prospect and the inferred extent of the se strata over an area of three blocks which were 57, 54, and 356 acres in size respectively. (See figure 6.) Core holes 1 and 2 were drilled in the 57-acre block. The thickness and grade of uranium-bearing strata penetrated in core hole 1 are so near to the average figures used in calculating the reserves that no adjustment is made in the reserve figures because of this new data. However, as core hole 2 did not penetrate the expected thickness of uraniferous strata, an adjustment must 
be made for the inferred reserves in the 57 -acre block. Samples collected at localities 9, 10, 11, and 12 extend neaxly the entire length of the block so it has been arbitrarily decided to reduce the size of the block from 57 to 50 acres. (See table 3.) Core holes 3 and 4 were drilled in the 54-acre block, and because both holes failed to penetrate the uranium-bearing strata, it has been arbitxarily decided not to calculate any reserves for this block. Core hole 5 was drilled in the 356 acre block, but this hole failed to penetrate the uranium-bearing strata simply because of insufficient drilling depth. There is no reason to believe the strata would not be encountered by deeper drilling, so no change in the inferred reserves was made for this block.

The following table of inferred reserves is a re-evaluation of the reserves of uranium-bearing rock in the Fall Creek area based on the assumption that the strata are continuous in their observed or assumed thickness and grade for a minimum distance of 1,000 feet down the dip of the beds from their outcrop. On the basis of the aforementioned assumptions about 1,300 tons of uxanium in six and a half million tons of rock may be present in the Fall Creek area. 
Table 3.0eInferred reserves of uranium in the Fall Creek area

Block one (northeast flank of anticline, north of Fall Creek coal prospect)

\begin{tabular}{|c|c|c|c|c|c|c|}
\hline Rock type & Tons/acre foot & Size of area & $\begin{array}{c}\text { Thickness of } \\
\text { rock unit }\end{array}$ & $\begin{array}{c}\text { Uranium } \\
\text { (percent) }\end{array}$ & Tons of rock & $\begin{array}{l}\text { Tons of } \\
\text { uranium }\end{array}$ \\
\hline $\begin{array}{l}\text { Limestone } \\
\text { Carb. shale } \\
\text { Coaly sh. (top) } \\
\text { Coaly sh. (base) }\end{array}$ & $\begin{array}{l}3,600 \\
2,600 \\
1,750 \\
1_{8} 750\end{array}$ & $\begin{array}{l}50 \text { acres } \\
\text { do. } \\
\text { do. } \\
\text { do. }\end{array}$ & $\begin{array}{l}1.5 \text { feet } \\
1.5 \text { feet } \\
1.0 \text { feet } \\
3.0 \text { feet }\end{array}$ & $\begin{array}{l}0.02 \\
.024 \\
.045 \\
.011\end{array}$ & $\begin{array}{r}270,000 \\
195,000 \\
87,500 \\
262,500\end{array}$ & $\begin{array}{l}54 \\
47 \\
39 \\
29\end{array}$ \\
\hline
\end{tabular}

Block two (southwest flank of anticline, south of Fall Creek coal prospect)

No inferred reserves.

Block three (outcrop band half way between Fall Creek coal prospect and Skyline Ridge)

\begin{tabular}{lcccccc}
\hline Limestone & 3,600 & 356 acres & 1.5 feet & 0.02 & $1,920,000$ & 382 \\
Carb. shale & 2,600 & do. & 1.5 feet & .024 & $1,390,000$ & 333 \\
Coaly sh. (top) & 1,750 & do. & 1.0 feet & .045 & 623,000 & 280 \\
Coaly sh. (base) & 1,750 & do. & 3.0 feet & .011 & $1,870,000$ & 205 \\
\hline & & & Sub-totals & $5,803,000$ & 1,200 \\
& & & TOTALS & $6,618,000$ & 1,369 &
\end{tabular}




\section{LITERATURE CITED}

Caribou National Forest, Idaho, Utah and Wyoming, 1949: map, scale 1/250,000: U. S. Dept. of Agr., Forest Service.

Cooper, H. M., Snyder, N. H., Abernethy, R. F., Tarpley, E. C., and Swingle, R. J., 1947, Analyses of mine, tipple and delivered samples: U. S. Bur. Mines Technical Paper 696, p. 38.

Goldschmidt, V. M., 1937, The principles of distribution of chemical elements in minerals and rocks: Chem. Soc. Jour., p. 655-673.

Katchenkov, S. M. , 1952, On some general regularities of the accumulation of mineral elements in petroleum and hard coals: Akad. Nauk SSSR Doklady, v. 86, no. 4, p. 805-808, Moscow, 1952.

Kirkham, V. R. D. 1 1924, Geology and oil possibilities of Bingham, Bonneville, and Caribou Counties, Idaho: Idaho Bur. Mines and Geology Bull. 8.

Mansfield, G. R., 1920, Coal in eastern Idaho: U. S. Geol. Survey Bull. $716 \sim F$, p. $123-154$.

Ross, C. P. and Forrester, J. S., 1947, Geologic map of the state of Idaho: map, scale $1 / 500,000$ published by U. S. Geol. Survey and Idaho Bur. Mines and Geology.

Rankama, Kalervo and Sahama, Th. G., 1950, Geochemistry: The Univ. of Chicago Press.

Tolmachev, I. M. , 1943, Adsorption of uranyl salts on solid adsorbents: Izvestila Akad. Nauk SSSR, Otd. Khim. Nauk, no. 1, p. 28-34 (U.S.S.R. Acad. Sci. Bull. no. 1, p. 28-34).

Vine, J. D., and Moore, G. W., 1952a, Uranium-bearing coal and carbonaceous rocks in the Fall Creek area, Bonneville County, Idaho: U. S. Geol. Survey Circ. 212.

\section{UNPUBLISHED REPORTS}

Beroni, E. P., and Bauer, H. L., Jr., 1952, Reconnaissance for uraniferous lignites in North Dakota, South Dakota, Montana, and Wyoming: U. S. Geol. Survey Trace Elements Inv. Rept. 123. 
Breger, I. A. and Deul, Maurice, 1952, Status of investigations on the geochemistry and mineralogy of uraniferous lignites: U. S. Geol. Survey Trace Elements Inv. Rept. 284.

Denson, N. M., Bachman, G. O., and Zeller, H. D. , 1950, Summary of new information on uraniferous lignites in the Dakotas: $U$. $S$. Geol. Survey Trace Elements Memo. Rept. 175.

Gardner, L. S., 1952, Geologic map of the Irwin and part of the Hell Creek quadrangles, Idaho: U. S. Geol. Survey. (Unpublished manuscript map.)

Hail, W. J., Jr。 and Gill, J. R., 1953, Radioactive carbonaceous shale and lignite deposits in the Goose Creek district, Cassia County, Idaho: U. S. Geol. Survey Trace Elements Inv. Rept. 272.

Haught, O. L., 1954, On the occurrence and distribution of rare ele. ments in coal: A talk presented at a meeting of the Appalachian Geol. Soc., Charleston, W. Va., April 5, 1954.

Koppe, E. F, Erickson, E. S., Jr。, Trotter, C。 L., Good, R. S., Spackman, W., Jr., and Bates, T. F.。1954, An investigation of the mineralogy。 petrography and paleobotany of uraniumbearing shales and lignites, Scope B - lignites: U. S. Atomic Energy Comm。 NYO=6061, 3rd Ann. Rept., period Apr。1, 1953 to Mar. 31, 1954, Coll. Min。 Industries, Penn. State Univ., p. 49-53.

Masursky, Harold and Pipiringos, G。 N., 1953, Uranium-bearing coal in the Red Desert, Great Divide Basin, Sweetwater County, Wyoming: U. S. Geol. Survey Trace Elements Memo. Rept. 601.

Slaughter, A. L., and Nelson, J. Mo, 1946, Trace Elements reconnais sance in South Dakota and Wyoming, preliminary report: U. S. Geol. Survey Trace Elements Inv. Rept. 20.

Vine, J. D., 1953, Investigations in the Fall Creek area, Bonneville County, Idaho, during the 1952 field season- $-a$ preliminary report: U. S. Geol. Survey Trace Elements Memo. Rept. 555.

Vine, J. D. and Moore, G。 W. , $195 \mathrm{2b}$, Reconnais sance for uraniumbearing carbonaceous rocks in northwestern Colorado, south western Wyoming, and adjacent parts of Utah and Idaho: U. S. Geol. Survey Trace Elements Inv. Rept. 281.

Vine, J. D., Bachman, G。 O., Read, C. B., and Moore, G. W., 1953, Uranium-bearing coal and carbonaceous shale in La Ventana Mesa area, Sandoval County, New Mexico: U. S. Geol. Survey Trace Elements Inv. Rept.241. 
Wyant, D. G. and Beroni, E. P., 1950, Reconnaissance for trace ele ments in North Dakota and eastern Montana: U. S. Geol. Survey Trace Elements Inv. Rept. 61. 
APPEIDIX

\section{Analyses of samnles collected from the Fall Creek ard adjacent areas}

Table A.--Analyses of carbonaceous rocirs in the Rear River formation (except $y$ s noted)

$$
\text { Analyses by: }
$$

Chenistry: Maryse Deleraux. Harry Levine, Aucry Pietsch, Joseph Budinsky, Peterson,

R. Dhfour, W. P. Tucker, Carmen H. Hoy, S. Lundine

Radiation: Benjamin A. $M_{C} C_{n} 11$, S. Furman

\begin{tabular}{|c|c|c|c|c|c|c|c|c|c|}
\hline $\begin{array}{l}\text { Locallty } \\
\text { number } 1 /\end{array}$ & $\begin{array}{r}\text { Pield } \\
\text { number }\end{array}$ & $\begin{array}{l}\text { Lab. } \\
\text { number }\end{array}$ & Rock type $2 /$ & $\begin{array}{l}\text { Type of aample } \\
\text { and thickness } \\
\text { (inches) }\end{array}$ & $\begin{array}{l}\text { Location } \frac{3 /}{\left.R_{*}\right)} \\
(\text { Sec., T., }\end{array}$ & $\begin{array}{c}\text { Equivelent } \\
\text { uranium } \\
\text { (percent) }\end{array}$ & $\begin{array}{c}\text { Ash } \\
\left(800^{\circ} \mathrm{C}\right) \\
(\text { percent })\end{array}$ & $\begin{array}{c}\text { Uranium } \\
\text { In ash } \\
\text { (porcent) }\end{array}$ & $\begin{array}{l}\text { Uranium } \\
\text { in sample } \\
\text { (percent) }\end{array}$ \\
\hline $\begin{array}{c}1 . \\
(\text { Brinson } \\
\text { coal pros.) }\end{array}$ & $\begin{array}{r}\nabla I-1170 \\
1171 \\
1172\end{array}$ & $\begin{array}{r}95409 \\
D 7323 \\
D 74324\end{array}$ & $\begin{array}{l}\text { Coaly shalo } \\
\text { do } \\
\text { Limestone }\end{array}$ & $\begin{array}{l}\text { grab } \\
\text { grab } \\
\text { grab }\end{array}$ & $\begin{array}{c}34-2 \mathrm{~N}-40 \mathrm{~g} \\
\text { do } \\
\text { do }\end{array}$ & $\begin{array}{r}0.001 \\
.003 \\
.003\end{array}$ & $\begin{array}{l}70.1 \\
74.55 \\
-.\end{array}$ & $0 . \overline{0012}$ & $\begin{array}{r}-.-4 / \\
0.0015 \\
.0019\end{array}$ \\
\hline 2. & $\begin{array}{r}\nabla I-1045 \\
1046\end{array}$ & $\begin{array}{l}87722 \\
87723\end{array}$ & $\begin{array}{l}\text { Linestone } \\
\text { Black clay soil }\end{array}$ & $\begin{array}{l}\text { grab } \\
\text { prab }\end{array}$ & $\begin{array}{l}\text { ?- }-1 N-41 \mathrm{~S} \\
\text { do }\end{array}$ & $\begin{array}{l}.006 \\
.002\end{array}$ & $\begin{array}{l}59.6 \\
81.6\end{array}$ & .208 & .005 \\
\hline 3. & $\nabla I-1044$ & $87 ? 21$ & Linestone & grab & $13-2 N-413$ & .003 & 61.7 & - & -- \\
\hline $\begin{array}{l}4 . \\
\text { (PIne Cr. } \\
\text { Pags pros.) }\end{array}$ & $\begin{array}{r}\nabla I-1093 \\
1094 \\
1095 \\
1149\end{array}$ & $\begin{array}{l}90198 \\
00199 \\
90200 \\
95484\end{array}$ & $\begin{array}{l}\text { Coaly shale } \\
\text { Coaly limestone } \\
\text { Linestone } \\
\text { Selected coal }\end{array}$ & $\begin{array}{l}\text { erab } \\
\text { grab } \\
\text { grab } \\
\text { grab }\end{array}$ & $\begin{array}{l}25-3 \mathrm{~N}-4 \mathrm{HE} \\
\text { do } \\
\text { do } \\
\text { do }\end{array}$ & $\begin{array}{l}.003 \\
.001 \\
.001 \\
.002\end{array}$ & $\begin{array}{c}63.5 \\
53.5 \\
50.0\end{array}$ & $\begin{array}{l}-- \\
-\overline{-} \\
.003\end{array}$ & $\begin{array}{l}-- \\
-- \\
-00 ?\end{array}$ \\
\hline $\begin{array}{c}5 . \\
\text { (Horseshoe } \\
\text { Dist.) }\end{array}$ & $\begin{array}{r}\nabla I-1153 \\
1154\end{array}$ & $\begin{array}{l}95496 \\
95497\end{array}$ & $\begin{array}{l}\text { Coal on durp } \\
\text { Fossils in coal }\end{array}$ & $\begin{array}{l}\text { grab } \\
\text { grab }\end{array}$ & $\begin{array}{c}32-5 \mathrm{II}-2 /+\mathrm{E} \\
\text { do }\end{array}$ & .003 & $\begin{array}{l}36.2 \\
79.0\end{array}$ & .009 & .003 \\
\hline
\end{tabular}

I) Localties shown on figures 1 and 2 .

2) Arbitrary definitlons were used as follows: coal, less then 50 percent ish; coaly shale, 50 to 80 percent ash; carbonaceous shale, orer 90 percent esh.

3) Locations are all in Idaho except is noted.

4 With a fow exceptions, samples contaizing 0.003 percent equivalent uraniun or less were not analyzed chemicelly for uranium.

5) "a" is less than 0.001 percent equivialent uranium. 
Table 1.-Analyses of carbonaceous rocks in the Bear River formation (except as noted) -Continued.

\begin{tabular}{|c|c|c|c|c|c|c|c|c|c|}
\hline $\begin{array}{l}\text { Locality } \\
\text { number I/ }\end{array}$ & $\begin{array}{l}\text { Field } \\
\text { number }\end{array}$ & $\begin{array}{l}\text { Lab. } \\
\text { number }\end{array}$ & Rock typo $2 /$ & $\begin{array}{l}\text { Type of sample } \\
\text { and thickness } \\
\text { (inches) }\end{array}$ & $\begin{array}{c}\text { Locntion } \frac{3 /}{} \\
(\text { Soc., T., R.) }\end{array}$ & $\begin{array}{l}\text { Equivalent } \\
\text { uranium } \\
\text { (parcent) }\end{array}$ & $\begin{array}{c}48 h \\
\left(800^{\circ} \mathrm{C}\right) \\
(\text { percent })\end{array}$ & $\begin{array}{l}\text { Urenium } \\
\text { In ash } \\
\text { (percent) }\end{array}$ & $\begin{array}{l}\text { Ufanium } \\
\text { In eample } \\
\text { (percent) }\end{array}$ \\
\hline $\begin{array}{c}6 . \\
\text { (trench and } \\
\text { auger) }\end{array}$ & $\begin{array}{r}V I-1043 \\
1166 \\
1167 \\
1168 \\
1169\end{array}$ & $\begin{array}{l}87720 \\
95495 \\
95496 \\
95497 \\
95149\end{array}$ & $\begin{array}{l}\text { Black clay soll } \\
\text { do } \\
\text { do } \\
\text { do } \\
\text { Limestone }\end{array}$ & $\begin{array}{l}\text { Erab } \\
8 \text { auger } \\
8 \text { auger } \\
4 \text { auger } \\
2\end{array}$ & $\begin{array}{c}15-1 N-42 y \\
\text { do } \\
\text { do } \\
\text { do } \\
\text { do }\end{array}$ & $\begin{array}{l}0.004 \\
.004 \\
.004 \\
.003 \\
.003\end{array}$ & $\begin{array}{l}84.4 \\
84.4 \\
85.7 \\
86.7 \\
30.8\end{array}$ & $\begin{array}{l}. \\
.006 \\
.004 \\
-- \\
--\end{array}$ & $\begin{array}{l}.0 \\
.005 \\
.003 \\
-- \\
-\end{array}$ \\
\hline 7. & $\nabla 1-1042$ & 87719 & Inestone & $\mathrm{FT}^{\mathrm{T}} \mathrm{bb}$ & $? 4 x-2 V-420$ & .004 & 59.4 & - & -- \\
\hline 8. & VI-1080 & 90185 & Iimestone & $5 \times a b$ & $36-1 N-42 D$ & $a$ & - & - & - \\
\hline 9. & $\begin{array}{r}\nabla I-371 \\
372 \\
373\end{array}$ & $\begin{array}{l}66858 \\
66859 \\
66860\end{array}$ & $\begin{array}{l}\text { Selected conl } \\
\text { on dump } \\
\text { Coaly soll } \\
\text { Black clay soll }\end{array}$ & $\begin{array}{l}5 \mathrm{Frab} \\
5 \times 4 b \\
5 x a b\end{array}$ & $\begin{array}{l}d x-42 E \\
\text { do } \\
\text { do }\end{array}$ & $\begin{array}{l}.066 \\
.021 \\
.002\end{array}$ & $\begin{array}{c}37.0 \\
58.1 \\
-\end{array}$ & $\begin{array}{c}0.22 \\
.028 \\
.-\end{array}$ & $\begin{array}{c}0.08 \\
.016 \\
-\end{array}$ \\
\hline$\stackrel{10 .}{\text { (trench) }}$ & $\begin{array}{r}\nabla I-1036 \\
1033 \\
1034 \\
1035\end{array}$ & $\begin{array}{l}87713 \\
87710 \\
87711 \\
87712\end{array}$ & $\begin{array}{l}\text { Limestone } \\
\text { Coaly ahale } \\
\text { do } \\
\text { do }\end{array}$ & $\begin{array}{r}18 \\
9 \\
9 \\
17\end{array}$ & $\begin{array}{l}40-1 S d+2 E \\
d 0 \\
d 0 \\
d 0\end{array}$ & $\begin{array}{l}.013 \\
.008 \\
.011 \\
.010\end{array}$ & $\begin{array}{l}61.5 \\
70.2 \\
75.1 \\
71.2\end{array}$ & $\begin{array}{l}.017 \\
.009 \\
.014 \\
.011\end{array}$ & $\begin{array}{l}.010 \\
.006 \\
.011 \\
.008\end{array}$ \\
\hline$\stackrel{11 .}{\text { (trench) }}$ & $\begin{array}{r}\nabla I 138 \\
1134 \\
1135 \\
1136 \\
1137\end{array}$ & $\begin{array}{l}90223 \\
90219 \\
90220 \\
90221 \\
90222\end{array}$ & $\begin{array}{l}\text { Llmeot tone } \\
\text { Carb. clay } \\
\text { do } \\
\text { Coaly shale } \\
\text { do }\end{array}$ & $\begin{array}{c}5 \times 86 \\
6 \\
6 \\
6 \\
6\end{array}$ & $\begin{array}{l}4-1 s-4 ? \mathrm{x} \\
\text { do } \\
\text { do } \\
\text { do } \\
\text { do }\end{array}$ & $\begin{array}{r}.008 \\
.008 \\
.013 \\
.017 \\
.021\end{array}$ & $\begin{array}{l}83.6 \\
83.3 \\
69.8 \\
66.8\end{array}$ & $\begin{array}{l}.- \\
.007 \\
.009 \\
.021 \\
.023\end{array}$ & $\begin{array}{l}.007 \\
.006 \\
.007 \\
.015 \\
.015\end{array}$ \\
\hline $\begin{array}{c}12 . \\
\text { (trench) }\end{array}$ & $\begin{array}{r}\nabla I-1133 \\
1132\end{array}$ & $\begin{array}{l}90218 \\
90217\end{array}$ & $\begin{array}{l}\text { Ifmes tone } \\
\text { Coaly shale }\end{array}$ & $\begin{array}{l}\text { grab } \\
\text { grab }\end{array}$ & $\begin{array}{c}\text { 4-1S-42I } \\
\text { do }\end{array}$ & $\begin{array}{l}.013 \\
.009\end{array}$ & 74.4 & .008 & $\begin{array}{l}.012 \\
.006\end{array}$ \\
\hline
\end{tabular}

13. The following samples are grouped in suites collected from vertical sections at intervals along the length of the $85-$ foot inclined shaft at the Fall Creek coal prospect.

(Tall Creak coal prospect) Samples collected at entry to inclined shoft.

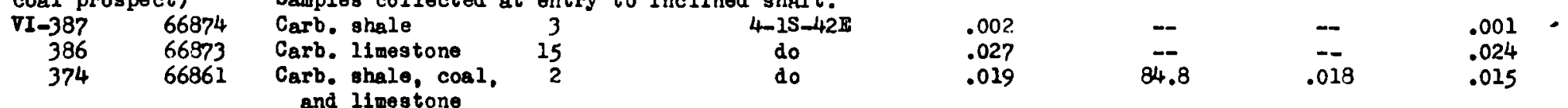


Table 4.--Analyses of carbonacesus rocks in the Bear River formation (except as noted)--Continued.

\begin{tabular}{|c|c|c|c|c|c|c|c|c|c|}
\hline $\begin{array}{l}\text { Localfty } \\
\text { aumber I/ }\end{array}$ & $\begin{array}{l}\text { Pield } \\
\text { number }\end{array}$ & Lab. & Rock type 2/ & $\begin{array}{l}\text { Type of sample } \\
\text { and thickness } \\
\text { (Inches) }\end{array}$ & $\begin{array}{c}\text { Location } \frac{3 /}{\left.R_{.}\right)} \\
(\text {Sec., T., }\end{array}$ & $\begin{array}{l}\text { Equivalent } \\
\text { uranium } \\
\text { (percent) }\end{array}$ & $\begin{array}{c}\text { Ash } \\
\left(800^{\circ} \mathrm{C}\right) \\
(\text { percent) }\end{array}$ & $\begin{array}{c}\text { Uranium } \\
\text { In ash } \\
\text { (percent) }\end{array}$ & $\begin{array}{l}\text { Uranium } \\
\text { in sample } \\
\text { (percent) }\end{array}$ \\
\hline \multicolumn{10}{|c|}{$13 .(\operatorname{con} t)}$. \\
\hline & $\begin{array}{r}\nabla I-375 \\
376 \\
377 \\
378 \\
379\end{array}$ & $\begin{array}{l}66862 \\
66863 \\
66864 \\
66865 \\
66866\end{array}$ & $\begin{array}{l}\text { Sheared coaly sh. } \\
\text { do } \\
\text { do } \\
\text { Carb. limestone } \\
\text { Carb. shale }\end{array}$ & $\begin{array}{r}15 \\
15 \\
15 \\
6 \\
6\end{array}$ & $\begin{array}{l}\text { 4-1S-42J } \\
\text { do } \\
\text { do } \\
\text { do } \\
\text { do }\end{array}$ & $\begin{array}{l}0.011 \\
.013 \\
.009 \\
.007 \\
.004\end{array}$ & $\begin{array}{c}78.8 \\
74.6 \\
77.5 \\
-- \\
--\end{array}$ & $\begin{array}{c}0.014 \\
.025 \\
.016 \\
-- \\
--\end{array}$ & $\begin{array}{r}0.011 \\
.023 \\
.013 \\
.007 \\
.003\end{array}$ \\
\hline
\end{tabular}

Samples collected $10 \mathrm{ft}$. from entry to inclined shaft

$\begin{array}{rccr}\text { VI-380 } & 66967 & \text { Coaly shale } & 4 \\ 381 & 66868 & \text { Sheared coaly oh. } & 12 \\ 382 & 66869 & \text { do } & 12 \\ 383 & 66870 & \text { do } & 12 \\ 394 & 66871 & \text { do } & 12 \\ 385 & 66872 & \text { Coaly shale } & 12\end{array}$

4- $15-42 \mathrm{E}$
do
do
do
do
do

.021
.011
.017
.009
.005
.004

.012

77.5
69.4
71.5
73.0
72.6
72.3

\section{.029}

.013

.027

$\begin{array}{rl}73.0 & .022 \\ .009 & .025\end{array}$

$.005 \quad 72.6 \quad .005$

Samples collected $20 \mathrm{ft}$. from entry to Inclined shaft

$\begin{array}{cccc}\text { VI-388 } & 66875 & \begin{array}{c}\text { Carb. limestone } \\ \text { and shale }\end{array} & 6 \\ 389 & 66876 & \text { Sheared coaly sh. } & 12 \\ 390 & 66877 & \text { do } & 12 \\ 391 & 66879 & \text { do } & 12 \\ 392 & 66879 & \text { Coaly shale } & 12 \\ 393 & 66890 & \text { Carb. limestone } & 12 \\ & & \text { and shale }\end{array}$

do
do
do
do
do

Samples collected $30 \mathrm{ft}$. from entry to inclined shaft

$\begin{array}{rccc}\nabla I-394 & 66931 & \text { Carb. shale } & 12 \\ 395 & 66832 & \text { Sheared coaly sh. } & 16 \\ 396 & 66883 & \text { do } & 16 \\ 397 & 66834 & \text { do } & 16 \\ 393 & 66835 & \text { Sheared coaly sh. } & 15 \\ & & \text { carb. sh., and is. }\end{array}$

4-1S-42.E
do
do
do
do
.024
.008
.007
.007

72.0
58.3
69.7
74.4

$-\overline{014}$

.014

.014

carb. sh., and is. 
… In the Bear River formation (except as noted)--Continued.

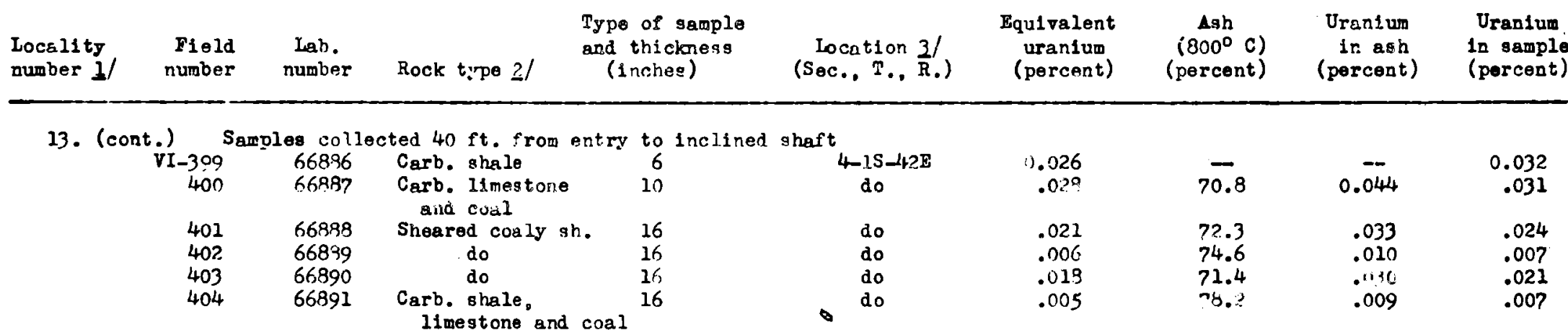

Samples collected $50 \mathrm{ft}$. from entry to inclined shaft

$\begin{array}{rrcr}\text { VI-405 } & 66892 & \begin{array}{c}\text { Carb. shale and 1s。 } \\ \text { Carb. limestone } \\ \text { shale, and coal }\end{array} \\ 406 & 66893 & \begin{array}{c}66894 \\ \text { Sheared coaly sho }\end{array} \\ 408 & 66895 & \text { do } \\ 409 & 66896 & \text { do } \\ 410 & 67239 & \begin{array}{c}\text { Carb. shale and } \\ \text { coal }\end{array}\end{array}$

dio
do +27
do
do
do

.026
.025
.033
.007
.005
.0116

$\cdots$
--
60.4
66.0
70.8
70.3

$\begin{array}{lll}- & .030 & .027 \\ .0 & .027 & 0 \\ .066 & .040 & 0 \\ .013 & .009 & .007 \\ .010 & .006 & \end{array}$

Samples collected $50 \mathrm{ft}$. from ontry to inclined shaft

$\begin{array}{rrlrc}\nabla I-411 & 67240 & \text { Carb. shale } & 8 & 4 \text { dS }-1+2 E \\ 412 & 67241 & \text { Carb. Iimestone } & 15 & \text { do } \\ 413 & 67242 & \text { Shearad coal } & 15 & \text { do } \\ 414 & 67243 & \text { Sheared coaly sh. } & 15 & \text { do } \\ 415 & 67244 & \text { do } & 15 & \text { do } \\ 416 & 67245 & \text { do } & 15 & \text { do }\end{array}$

Samples collected $75 \mathrm{ft}$. from entry to inclined siaft

$\begin{array}{rrlr}\nabla I-117 & 67246 & \text { Carb. shale } & 4 \\ 418 & 67247 & \text { Carb. limestone } & 17 \\ 419 & 67248 & \text { Sheared coaly sh. } & 13 \\ 420 & 67249 & \text { do } & 13 \\ 421 & 67250 & \text { do } & 13\end{array}$

4-1S-4?
do
do
do
do

$\begin{array}{lc}.016 & -- \\ .018 & -- \\ .040 & 43.7 \\ .025 & 66.2 \\ .006 & 75.9 \\ .007 & 77.4\end{array}$

$\begin{array}{ll}-- & .020 \\ -- & .022 \\ .300 & .131 \\ .044 & .029 \\ .010 & .008 \\ .009- & .007\end{array}$

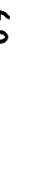


Table 4.--Anelyses of carbonaceoug rocks in the Bear River formation (except as noted)--Continued.

\begin{tabular}{|c|c|c|c|c|c|c|c|c|c|}
\hline $\begin{array}{l}\text { Locallty } \\
\text { number } \mathrm{J} /\end{array}$ & $\begin{array}{l}\text { Pleld } \\
\text { nunber }\end{array}$ & $\begin{array}{l}\text { Lab. } \\
\text { number }\end{array}$ & Rock type 2/ & $\begin{array}{l}\text { Type of sample } \\
\text { and thickness } \\
\text { (1nches) }\end{array}$ & $\begin{array}{c}\text { Locetion } 3 / \\
(\text { Sec., T., R. }\end{array}$ & $\begin{array}{l}\text { Equivalent } \\
\text { uranium } \\
\text { (percent) }\end{array}$ & $\begin{array}{c}\text { Agh } \\
\left(800^{\circ} \mathrm{C}\right) \\
(\text { percent })\end{array}$ & $\begin{array}{c}\text { Uranlum } \\
\text { In ash } \\
\text { (percont) }\end{array}$ & $\begin{array}{l}\text { Uranium } \\
\text { in sample } \\
\text { (percent) }\end{array}$ \\
\hline
\end{tabular}

13. (cont.) Samples typical of the lithologic units represented in and near the F'all Creek coal prospect

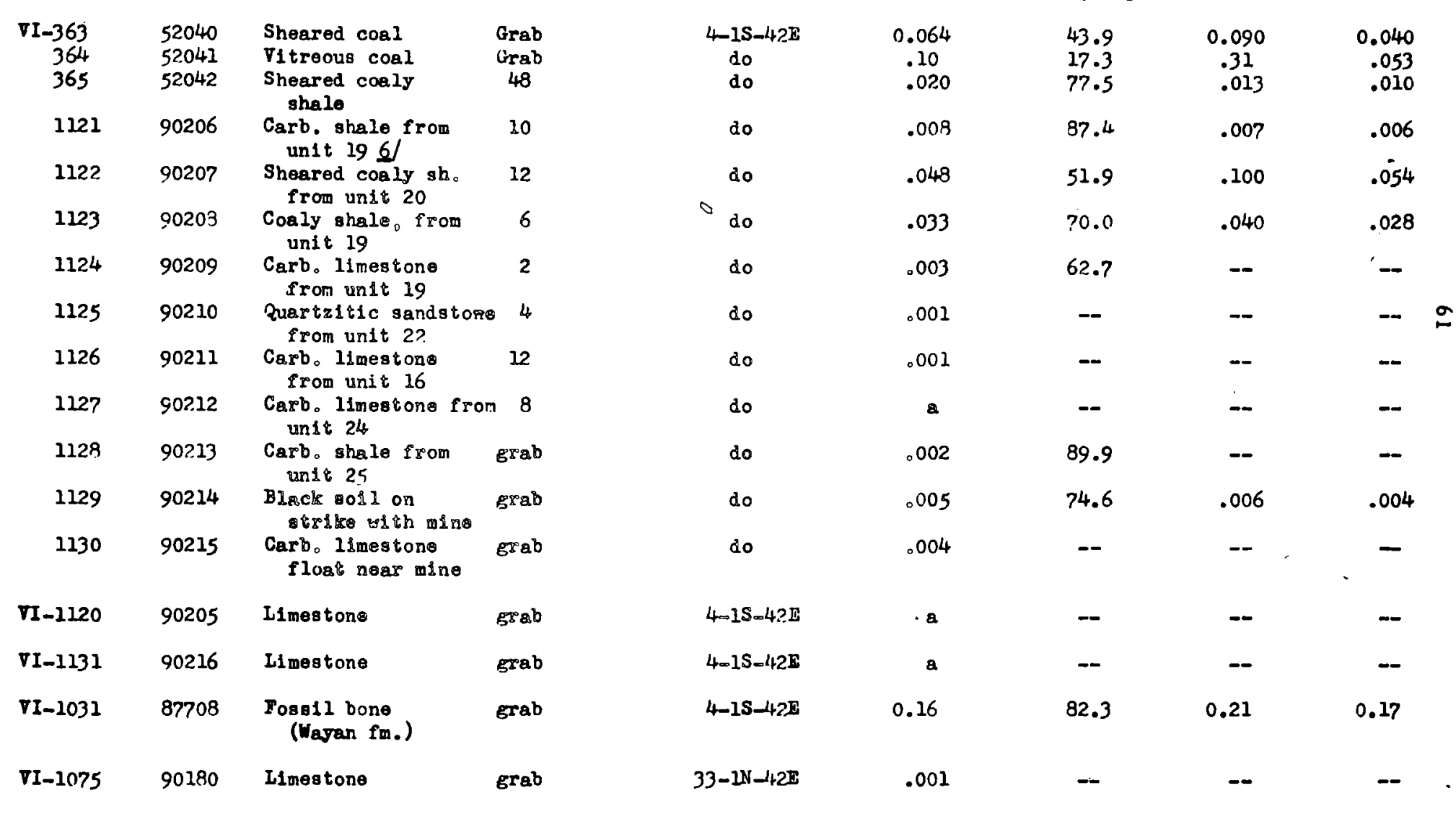

6) Un1t-numbers refer to the numbered lithologlc units in the columnar section, pege 27. 
Table A.-Analyses of carbonaceous rocks in the Bear River formation (except as noted)-Continued.

\begin{tabular}{|c|c|c|c|c|c|c|c|c|c|}
\hline $\begin{array}{l}\text { Locality } \\
\text { number } 1 / /\end{array}$ & $\begin{array}{l}\text { Field } \\
\text { number }\end{array}$ & $\begin{array}{l}\text { Lab. } \\
\text { number }\end{array}$ & Rock type $\underline{2} /$ & $\begin{array}{l}\text { Type of sample } \\
\text { and thickness } \\
\text { (Inches) }\end{array}$ & $\begin{array}{c}\left.\text { Locition } \frac{3}{R_{0}}\right) \\
(\text { Sec., T., }\end{array}$ & $\begin{array}{c}\text { Fquivalent } \\
\text { uranium } \\
\text { (percent) }\end{array}$ & 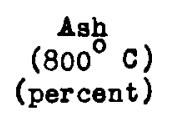 & $\begin{array}{c}\text { Uranium } \\
\text { in ash } \\
\text { (percent) }\end{array}$ & $\begin{array}{l}\text { Uranium } \\
\text { in sample } \\
\text { (percent) }\end{array}$ \\
\hline $\begin{array}{c}18 . \\
\text { (trench } \\
\text { and } \\
\text { auger) }\end{array}$ & $\begin{array}{r}\text { VI-1074 } \\
1071 \\
1072 \\
1073\end{array}$ & $\begin{array}{l}90179 \\
88112 \\
901174 \\
90118\end{array}$ & $\begin{array}{l}\text { Inestone } \\
\text { Gray clay soil } \\
\text { do } \\
\text { do }\end{array}$ & $\begin{array}{l}\text { grab } \\
10 \text {, auger } \\
16 \text {, auger } \\
16 \text {, auger }\end{array}$ & $\begin{array}{l}33-2 \mathrm{~N}-4+2 \mathrm{E} \\
\text { do } \\
\text { do } \\
\text { do }\end{array}$ & $\begin{array}{r}0.001 \\
.004 \\
.001 \\
.002\end{array}$ & $\begin{array}{l}-\overline{1.5} \\
88.1 \\
86.2\end{array}$ & $\begin{array}{l}- \\
-- \\
--\end{array}$ & $\begin{array}{l}-- \\
-- \\
--\end{array}$ \\
\hline 19. & VI-1041 & 87718 & Black clay soil & grab & $34-I N-42 \mathbb{E}$ & .004 & 85.3 & - & -- \\
\hline 20. & $\nabla I-1032$ & 87709 & Indestone & grab & $34-1 N-42 \mathbb{E}$ & .006 & 61.1 & 0.007 & 0.004 \\
\hline 21. & $V I-1040$ & 87717 & Sandy clay soll & Erab & $34-1 N-42 \mathbb{R}$ & .001 & 92.3 & - & - \\
\hline (trench) & $\begin{array}{r}\mathbf{n}-1038 \\
1039\end{array}$ & $\begin{array}{l}87715 \\
87716\end{array}$ & $\begin{array}{c}\text { Black clay soil } \\
\text { do }\end{array}$ & $\begin{array}{l}6 \\
6\end{array}$ & $\begin{array}{l}2-1 S-42 D \\
d o\end{array}$ & $\begin{array}{l}.007 \\
.007\end{array}$ & $\begin{array}{l}86.4 \\
86.6\end{array}$ & $\begin{array}{l}.005 \\
.007\end{array}$ & $\begin{array}{l}.004 \\
.006\end{array}$ \\
\hline 23. & VI-1087 & 90192 & $\begin{array}{l}\text { Himestone } \\
\text { (Draney ls.) }\end{array}$ & grab & $7-1 S-423$ & $\mathbf{a}$ & -- & -- & -- \\
\hline $\begin{array}{l}24 . \\
\text { (trench } \\
\text { and } \\
\text { auger) }\end{array}$ & $\begin{array}{r}\nabla-1047 \\
1048 \\
1052 \\
1049 \\
1050 \\
1051\end{array}$ & $\begin{array}{l}87724 \\
88089 \\
88093 \\
88090 \\
88091 \\
88092\end{array}$ & $\begin{array}{l}\text { Iimestone } \\
\text { Black clay soil } \\
\text { do } \\
\text { do } \\
\text { do } \\
\text { do }\end{array}$ & $\begin{array}{l}\text { Erab } \\
\text { Erab } \\
\text { grab } \\
\text { 7. auger } \\
\text { 14, auger } \\
\text { 28, auger }\end{array}$ & $\begin{array}{l}9-1 S-42 E \\
\text { do } \\
\text { do } \\
\text { do } \\
\text { do } \\
\text { do }\end{array}$ & $\begin{array}{l}.003 \\
.012 \\
.010 \\
.006 \\
.005 \\
.003\end{array}$ & $\begin{array}{l}61.9 \\
84.6 \\
83.2 \\
84.0 \\
85.4 \\
86.3\end{array}$ & $\begin{array}{l}-- \\
.013 \\
.010 \\
.005 \\
.004 \\
--\end{array}$ & $\begin{array}{l}.7 \\
.011 \\
.008 \\
.004 \\
.003 \\
. \infty\end{array}$ \\
\hline 25 & VI-1099 & 90204 & Limestone & grab & $12-15-42 E$ & a & -- & -- & -- \\
\hline 26. & VI-1098 & 90203 & Limes tone & grab & $7-15-438$ & a & - & -- & - \\
\hline $\begin{array}{l}27 . \\
\text { (trench } \\
\text { and } \\
\text { auger) }\end{array}$ & $\begin{array}{r}\text { VI-1053 } \\
1055 \\
1056 \\
1057\end{array}$ & $\begin{array}{l}88094 \\
88096 \\
88097 \\
88098\end{array}$ & $\begin{array}{l}\text { Llmestone } \\
\text { Black clay soll } \\
\text { do } \\
\text { do }\end{array}$ & $\begin{array}{l}\text { grab } \\
\text { 17, auger } \\
\text { 17, auger } \\
\text { 18, auger }\end{array}$ & $\begin{array}{c}16-1 S-42 E \\
\text { do } \\
\text { do } \\
\text { do }\end{array}$ & $\begin{array}{l}.003 \\
.004 \\
.012 \\
.006\end{array}$ & $\begin{array}{l}-- \\
85.6 \\
85.6 \\
88.5\end{array}$ & $\begin{array}{l}-- \\
.010 \\
.005\end{array}$ & $\begin{array}{l}-- \\
.009 \\
.004\end{array}$ \\
\hline 28. & $\nabla I-1088$ & 90193 & Limestone & grab & $16-1 S-42 \mathrm{~F}$ & .005 & - & -- & .004 \\
\hline 29. & $\begin{array}{r}V I-1092 \\
1091\end{array}$ & $\begin{array}{l}901197 \\
90196\end{array}$ & $\begin{array}{l}\text { Ilme日tone } \\
\text { Black clay soil }\end{array}$ & $\begin{array}{l}\text { grab } \\
\text { grab }\end{array}$ & $\begin{array}{c}22-1 S-42 E \\
\text { do }\end{array}$ & $\begin{array}{l}.004 \\
.003\end{array}$ & -- & -- & -- \\
\hline
\end{tabular}


Table A.--Analyses of carbonaceous rocks in the Bear River formation (except as noted)--Contimed.

\begin{tabular}{|c|c|c|c|c|c|c|c|c|c|}
\hline $\begin{array}{l}\text { Locality } \\
\text { number I/ }\end{array}$ & $\begin{array}{r}\text { Fiold } \\
\text { number }\end{array}$ & $\begin{array}{l}\text { Iab. } \\
\text { number }\end{array}$ & Rock type $2 /$ & $\begin{array}{l}\text { Type of sample } \\
\text { and thickness } \\
\text { (inches) }\end{array}$ & $\begin{array}{c}\text { Location } 3 / \\
\left(\text { Sec., T. . K. }_{\text {. }}\right)\end{array}$ & $\begin{array}{c}\text { Equivalent } \\
\text { uranium } \\
\text { (percent) }\end{array}$ & $\begin{array}{c}\text { Ash } \\
\left(300^{\circ} \mathrm{C}\right) \\
(\text { percent })\end{array}$ & $\begin{array}{l}\text { Urantum } \\
\text { in ash } \\
\text { (percent) }\end{array}$ & $\begin{array}{l}\text { Urantum } \\
\text { In gample } \\
\text { (percent) }\end{array}$ \\
\hline $\begin{array}{c}30 . \\
\text { (auger) }\end{array}$ & $\begin{array}{r}\text { VI-1089 } \\
1142 \\
1143 \\
1144 \\
1145 \\
1146 \\
1147\end{array}$ & $\begin{array}{l}90194 \\
95478 \\
95479 \\
95480 \\
95481 \\
95482 \\
95483\end{array}$ & $\begin{array}{l}\text { Ilmestone } \\
\text { Brown clas soll } \\
\text { do } \\
\text { do } \\
\text { do } \\
\text { do } \\
\text { do }\end{array}$ & $\begin{array}{l}\text { Erab } \\
9 \text {, auger } \\
\text { o, auger } \\
9 \text {, auger } \\
9 \text {, auger } \\
9 \text {, auger } \\
9 \text {, auger }\end{array}$ & $\begin{array}{l}27-15-4 ? .13 \\
\text { do } \\
\text { do } \\
\text { do } \\
\text { do } \\
\text { do } \\
\text { do }\end{array}$ & $\begin{array}{l}0.006 \\
.002 \\
.004 \\
.003 \\
.003 \\
.003 \\
.003\end{array}$ & $\begin{array}{l}-- \\
85.4 \\
88.4 \\
84.7 \\
87.3 \\
88.0 \\
88.1\end{array}$ & $\begin{array}{c}-- \\
-- \\
0.003 \\
-- \\
-- \\
-- \\
--\end{array}$ & $\begin{array}{l}0.004 \\
-- \\
.003 \\
=- \\
-- \\
=- \\
-\end{array}$ \\
\hline 31. & $\nabla I-1090$ & 90195 & Limes tone & grab & $23-1 S-4+2 E$ & .002 & -- & - & -- \\
\hline 32. & $V I-1054$ & 88095 & Limestone & ETab & $25-15-42 E$ & .004 & - & -- & -- \\
\hline 33. & $V I-1058$ & 83099 & Black soil & Erab & $1-2 S-42 E$ & .002 & 87.7 & -- & -- \\
\hline $\begin{array}{l}34 . \\
\text { (trench } \\
\text { and } \\
\text { auger) }\end{array}$ & $\begin{array}{r}\text { VI-1060 } \\
1059 \\
1061 \\
1062 \\
1063 \\
1064\end{array}$ & $\begin{array}{l}83101 \\
88100 \\
88102 \\
88013 \\
88014 \\
88015\end{array}$ & $\begin{array}{l}\text { Limestone } \\
\text { Black clay soil } \\
\text { do } \\
\text { do } \\
\text { Gray clay soll } \\
\text { Sands clay soll }\end{array}$ & $\begin{array}{l}\text { grab } \\
18 \\
\text { 8. auger } \\
8 \text {, auger } \\
8 \text { ouger } \\
8 \text {, auger }\end{array}$ & $\begin{array}{l}6-2 S-43 E \\
\text { do } \\
\text { do } \\
\text { do } \\
\text { do } \\
\text { do }\end{array}$ & $\begin{array}{l}.004 \\
.003 \\
.002 \\
.002 \\
.003 \\
.002\end{array}$ & $\begin{array}{l}-- \\
83.4 \\
80.6 \\
80.7 \\
82.7 \\
90.0\end{array}$ & $\begin{array}{l}-- \\
-- \\
-- \\
-- \\
-- \\
--\end{array}$ & $\begin{array}{l}-- \\
-+ \\
-- \\
-- \\
--\end{array}$ \\
\hline 35. & VI-1065 & 89016 & $\begin{array}{l}\text { Limestone } \\
\text { (Draney 18.) }\end{array}$ & grab & $17-2 S-43 E$ & $\mathbf{a}$ & - & $-\quad-$ & -- \\
\hline 36. & $\begin{array}{r}V I-1174 \\
1173\end{array}$ & $\begin{array}{l}\text { D7 } 4326 \\
D 74325\end{array}$ & $\begin{array}{l}\text { Limestone } \\
\text { Coaly shale }\end{array}$ & $\begin{array}{l}24 \\
12\end{array}$ & $\begin{array}{c}18-2 S-45 E \\
\text { do }\end{array}$ & $\begin{array}{l}.002 \\
.004\end{array}$ & $\overline{77.53}$ & .0042 & .0011 \\
\hline $\begin{array}{c}37 . \\
\text { (Croley } \\
\text { coal } \\
\text { pros.) }\end{array}$ & $\begin{array}{r}V I-1140 \\
1241\end{array}$ & $\begin{array}{l}95476 \\
35477\end{array}$ & $\begin{array}{l}\text { Selected coal } \\
\text { on dump } \\
\text { Average material } \\
\text { on coal dump }\end{array}$ & $\begin{array}{l}\text { Erab } \\
\text { grab }\end{array}$ & $\begin{array}{l}27-15-41 E \\
\text { do }\end{array}$ & $\begin{array}{l}.005 \\
.003\end{array}$ & $\begin{array}{l}21.7 \\
48.6\end{array}$ & $\begin{array}{l}.030 \\
.004\end{array}$ & $\begin{array}{l}.007 \\
.002\end{array}$ \\
\hline $\begin{array}{l}38 . \\
\text { (trench) }\end{array}$ & $\begin{array}{r}V I-1066 \\
1067 \\
1068 \\
1069\end{array}$ & $\begin{array}{l}88107 \\
88108 \\
88109 \\
88110\end{array}$ & $\begin{array}{l}\text { Coaly shale } \\
\text { Carb. clay } \\
\text { do } \\
\text { do }\end{array}$ & $\begin{array}{l}9 \\
9 \\
9 \\
9\end{array}$ & $\begin{array}{l}23-3 S-4+3 E \\
\text { do } \\
\text { do } \\
\text { do }\end{array}$ & $\begin{array}{l}.011 \\
.006 \\
.005 \\
.006\end{array}$ & $\begin{array}{l}69.9 \\
81.6 \\
83.1 \\
79.9\end{array}$ & $\begin{array}{l}.019 \\
.007 \\
.006 \\
.009\end{array}$ & $\begin{array}{r}.013 \\
.006 \\
.005 \\
.007 \\
-\quad .\end{array}$ \\
\hline
\end{tabular}


Table A.-manalyses of carbonaceous rocks in the Bear River formation (except as noted)--Continued.

\begin{tabular}{|c|c|c|c|c|c|c|c|c|c|}
\hline $\begin{array}{l}\text { Locality } \\
\text { number I/ }\end{array}$ & $\begin{array}{l}\text { Field } \\
\text { number }\end{array}$ & $\begin{array}{l}\text { Iab. } \\
\text { number }\end{array}$ & Rock type $2 /$ & $\begin{array}{l}\text { Type of sample } \\
\text { and thickesess } \\
\text { (inches) }\end{array}$ & $\begin{array}{c}\text { Locition } 3 / \\
\left(\operatorname{Sec}_{0} T_{0}, \mathrm{H}_{0}\right)\end{array}$ & $\begin{array}{c}\text { Equf palent } \\
\text { uranium } \\
\text { (percent) }\end{array}$ & $\begin{array}{c}\stackrel{\mathrm{sh}}{\left(300^{\circ} \mathrm{C}\right)} \\
(\text { percent })\end{array}$ & $\begin{array}{c}\text { Uranlum } \\
\text { in ash } \\
\text { (percent) }\end{array}$ & $\begin{array}{l}\text { Oranium } \\
\text { in sample } \\
\text { (percent) }\end{array}$ \\
\hline 39. & $\nabla I-1070$ & 88111 & $c_{a r b}$ shale & $1 ?$ & $2.4-35244 \mathrm{~b}$ & 0.001 & 82.4 & -- & -- \\
\hline 40 & $\begin{array}{r}V *-108 ? \\
1083 \\
1084\end{array}$ & $\begin{array}{l}90187 \\
90188 \\
90189\end{array}$ & $\begin{array}{l}\text { Ilmestoine } \\
\text { Black shale } \\
\text { Conglomerate }\end{array}$ & $\begin{array}{l}\text { Erab } \\
12 \\
14\end{array}$ & $\begin{array}{l}4-37 \mathrm{~N}-117 \mathrm{~W} \\
\text { (wyoning) } \\
\text { do }\end{array}$ & $\begin{array}{c}.003 \\
.001 \\
e\end{array}$ & $\begin{array}{l}=- \\
91.9 \\
85.7\end{array}$ & $\begin{array}{l}-- \\
--\end{array}$ & - \\
\hline $\begin{array}{l}41 . \\
\text { (Auburn } \\
\text { coal }\end{array}$ & $\nabla W-1190$ & D74342 & Carb。 shale & grab & $\begin{array}{r}5-32 \mathrm{~N}-119 \mathrm{~W} \\
\text { (Wyoming) }\end{array}$ & .004 & 88.01 & 0.0053 & 0.0035 \\
\hline
\end{tabular}


Analysea by W. Niles, W. Montjoy and R. Dufour (Chemigtry) and S. Furman (Radiation).

Table B.-Analyses of silicic volcanic rocks

\begin{tabular}{|c|c|c|c|c|c|c|}
\hline $\begin{array}{l}\text { Iocelity } \\
\text { number IJ }\end{array}$ & $\begin{array}{l}\text { Location } \\
\left(\text { Sec.. T., R. }_{\text {. }}\right)\end{array}$ & $\begin{array}{l}\text { Field } \\
\text { number }\end{array}$ & $\begin{array}{l}\text { Iab. } \\
\text { number }\end{array}$ & Rock type & $\begin{array}{c}\text { Equivalent } \\
\text { uranium } \\
\text { (percent) }\end{array}$ & $\begin{array}{c}\text { Urantum } \\
\text { in sample } \\
\text { (percent) } 2\end{array}$ \\
\hline 1. & $\begin{array}{c}25-5 \mathrm{~N}-44 \mathrm{I} \\
\text { do }\end{array}$ & $\begin{array}{r}\nabla I-367 \\
368 a\end{array}$ & $\begin{array}{r}66854 \\
D 84780\end{array}$ & $\begin{array}{l}\text { Vesicular lava } \\
\text { Tuff }\end{array}$ & $\begin{array}{r}0.004 \\
.004\end{array}$ & $0 . \overline{0012}$ \\
\hline 2. & $19-317-465$ & VI-1096 & D84787 & Rhyolite & .004 & .0010 \\
\hline 3. & $1-2 \mathrm{~N}-40 \mathrm{P}$ & $V I-1151$ & D73712 & Tuff & .002 & .0005 \\
\hline 4. & $25-2 N-43 \mathrm{E}$ & $V-1148$ & D73711 & Pumiceous loess & .001 & .0003 \\
\hline 5. & $11-1 N-40$ I & $\nabla I-366 a$ & D84779 & Rhyolitic tuff & .003 & .0007 \\
\hline 6. & $21-1 N-42 \pi$ & $V I-1030$ & D84785 & Obsidian & .004 & .0012 \\
\hline 7. & $30-1 N-42 N$ & $V I-1037$ & 87714 & Rhyolitic tuff & .004 & -- \\
\hline 8. & $29-1 W-42 \mathbb{E}$ & $\nabla I-370 a$ & D84782 & do & .004 & .0010 \\
\hline 9. & $8-15-42 \pi$ & $\nabla I-1081$ & D84 4786 & do & .004 & .0012 \\
\hline 10. & $29-15-42 \pi$ & VI-1139 & 90224 & do & .004 & - \\
\hline 21. & $16-1 S-45 \pi$ & $V I-369 a$ & D34781 & Tuffaceous $a_{2}$ nd & .004 & .0010 \\
\hline 12. & $\begin{array}{c}16-3 S-46 \mathrm{~s} \\
\text { do }\end{array}$ & $\begin{array}{r}V I-1085 \\
1086\end{array}$ & $\begin{array}{l}90190 \\
90191\end{array}$ & $\begin{array}{l}\text { Tuffeceous sand } \\
\text { Tuff }\end{array}$ & $\begin{array}{l}.004 \\
.001\end{array}$ & -- \\
\hline $1 /$ & \multicolumn{6}{|c|}{ Locality shown on figures 1 and 2 . } \\
\hline$\underline{2} /$ & $\begin{array}{l}\text { Samples that } \\
\text { laboratory we }\end{array}$ & 0.005 & quival & m or less by ra & surements & hington \\
\hline
\end{tabular}


Analyses $b y$ W. Niles and w. Montjoy

Table C.--Analyses of natural waters

\begin{tabular}{|c|c|c|c|c|c|}
\hline $\begin{array}{l}\text { Locality } \\
\text { number I/ }\end{array}$ & $\begin{array}{l}\text { Location } \\
(\operatorname{Sec} ., \text { T., R.) }\end{array}$ & $\begin{array}{l}\text { Fleld } \\
\text { number }\end{array}$ & $\begin{array}{l}\text { Lab. } \\
\text { number }\end{array}$ & $\begin{array}{l}\text { Uranium } \\
\text { (ppm) }\end{array}$ & Description \\
\hline 1. & $32-2 \mathrm{~N}-42 \mathrm{Z}$ & VI-II05 & $D 73709$ & $<0.002$ & Spring at base of silicic volcanic rocks \\
\hline 2. & $3 I-2 N-4 I 5$ & $\nabla I-11) / 4$ & D73707 & .005 & $\begin{array}{l}\text { Spring in Wayan formation just below con- } \\
\text { tact with, silicic volcanic rocks }\end{array}$ \\
\hline 3. & $3-2 X-4+3 E$ & VI-!10 & $D 73709$ & si. 002 & Mineral spring on Fall Creok \\
\hline 4. & $23-1 N-43$ & VI-1I 33 & D73706 & $\$ .002$ & $\begin{array}{l}\text { Spring in wayan formation just below con- } \\
\text { tact with silicle volcanic rocks }\end{array}$ \\
\hline 5. & $32-1:-422$ & VI-ilol & D73704 & .003 & $\begin{array}{l}\text { Spring in wayan formation about } 500 \text { feet } \\
\text { below contact with silicic volcanic rocks }\end{array}$ \\
\hline ó. & $33-1+4-423$ & VI-1102 & D73705 & .003 & $\begin{array}{l}\text { Spring at Fall Creek Ranger } \mathrm{St}_{g} \text { tion along } \\
\text { a synclinal axis in tre hejan formation. } \\
\text { \& remant of silicic rolcanic rocks over- } \\
\text { lies the synclinal axis about } 1 \frac{1}{s} \text { ofleg to } \\
\text { the northwest. }\end{array}$ \\
\hline 7. & $\begin{array}{l}\text { 4-3?N-i17w } \\
\text { (wyomirg) }\end{array}$ & $\nabla i-1100$ & D73703 & $<0.002$ & Snake River water \\
\hline
\end{tabular}

1) Localities shown on figures 1 and 2. 
Aralyges by Alice Padgett (Chomlatry) and B. A. MrCall (Radiation)

Table D.--Core analyses

\begin{tabular}{|c|c|c|c|c|c|c|c|c|c|}
\hline $\begin{array}{c}\text { Core } \\
\text { hole } \\
\text { namber }\end{array}$ & $\begin{array}{l}\text { Field } \\
\text { number }\end{array}$ & $\begin{array}{l}\text { Inab. } \\
\text { number }\end{array}$ & Rock tJpe & $\begin{array}{l}\text { Depth } \\
\text { sarpled } \\
\text { (feet) }\end{array}$ & $\begin{array}{l}\text { Th1 ckness } \\
\text { of unit } \\
(f \theta \theta t)\end{array}$ & $\begin{array}{c}\text { Equivalent } \\
\text { uranium } \\
\text { (percent) }\end{array}$ & $\begin{array}{c}\text { Ash } \\
\text { (percent) }\end{array}$ & $\begin{array}{c}\text { Urantum } \\
\text { In ash } \\
\text { (percent) }\end{array}$ & $\begin{array}{l}\text { Urantum } \\
\text { in sample } \\
\text { (percent) }\end{array}$ \\
\hline & & & & & & & & & \\
\hline 1 & VI-1300 & 113580 & L1mestone & $261.9-262.5$ & 0.6 & 0.003 & -- & - & 0.003 \\
\hline$i$ & $\bar{V}-1301$ & 113581 & do & $262.5-263.5$ & 1.0 & .003 & -- & - & .004 \\
\hline 1 & VI-1302 & 113582 & do & $263.5-264.5$ & 1.0 & .003 & -- & - & .003 \\
\hline 1 & $71-1303$ & 113583 & do & $264.5-265.5$ & 1.0 & .007 & -- & - & .007 \\
\hline 1 & $\nabla I-1304$ & 113584 & do & $265.5-266.5$ & 1.0 & .013 & -- & - & .014 \\
\hline 1 & $V I-1305$ & 113535 & Coaly shale & $266.5-267.7$ & 1.2 & .020 & 77.1 & 0.036 & .028 \\
\hline 1 & & & Core loss & $267.7-269.0$ & 1.3 & -- & -- & - & - \\
\hline 1 & $\nabla I-1306$ & 113586 & Coaly shale & $269.0-269.5$ & 0.5 & .025 & 70.0 & .056 & .039 \\
\hline 1 & $\nabla I-1307$ & 113587 & do & $269.5-270.5$ & 1.0 & .023 & 69.0 & .039 & .028 \\
\hline 2 & $\nabla I-1308$ & 113588 & Carb. shale & $246.3-247.2$ & - & .006 & - & - & - \\
\hline 44 & $M I-1004$ & 115800 & Conelonerate & $51.5-52.0$ & 0.5 & .004 & - & - & .003 \\
\hline 44 & KI -1005 & 115301 & do & $52.0-52.5$ & 0.5 & .004 & -- & - & .003 \\
\hline
\end{tabular}


Analyses by Mona Frank, C. L. Waring, K. G. Ilavens, Audry Smith

Elements looked for but not detected: Au, As, Bi, Cd, Ce, Dy, Sr, Gd, Hf

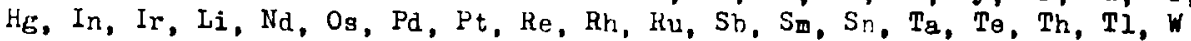

Table E.-.Semi-quantititive spectrographic analyses

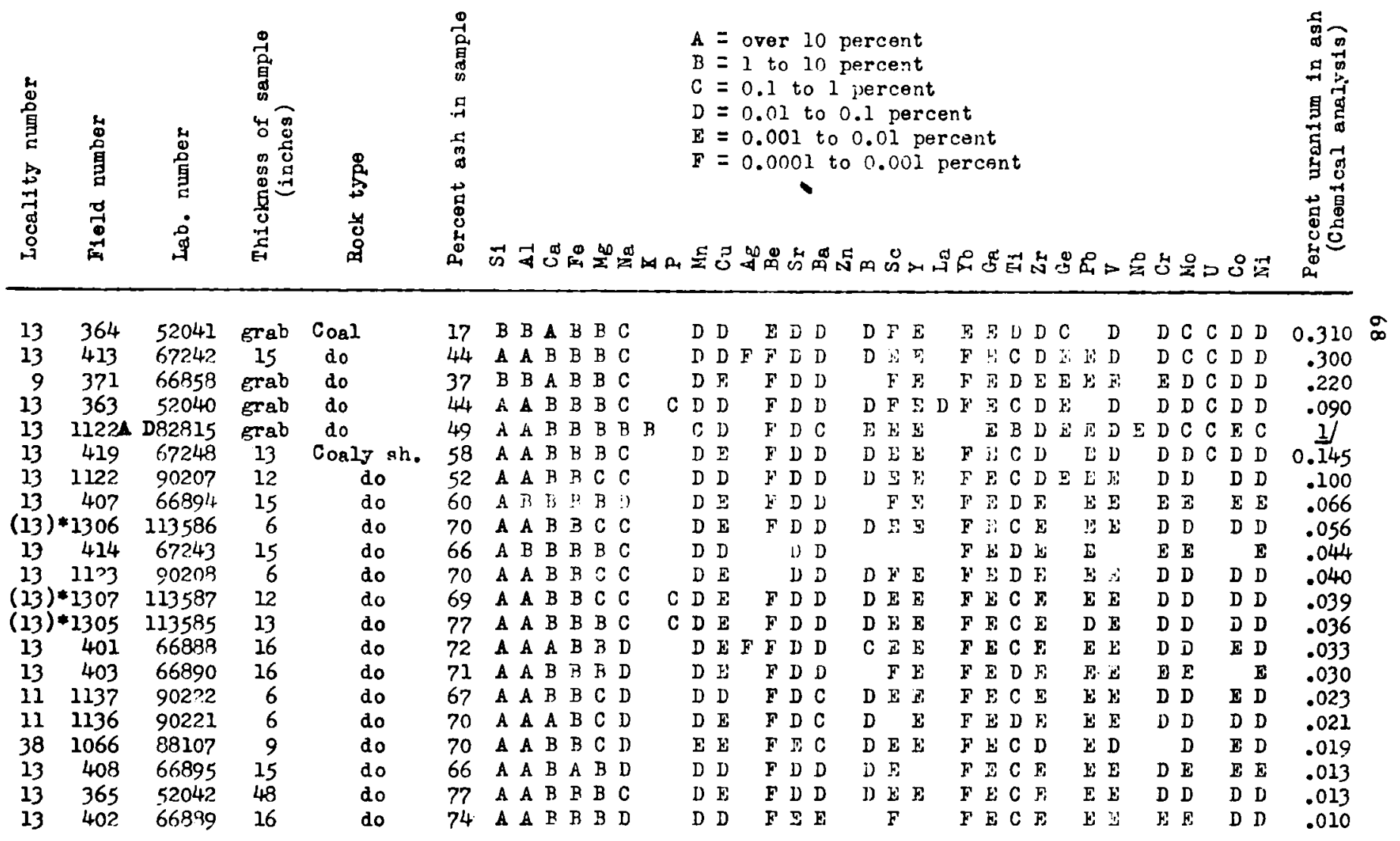

* Core hole number 1

1) This sample wag too small for chemical analysis 
$T_{q}$ ble E.--Sem1-quartitative spectrographic analyses--Continued.

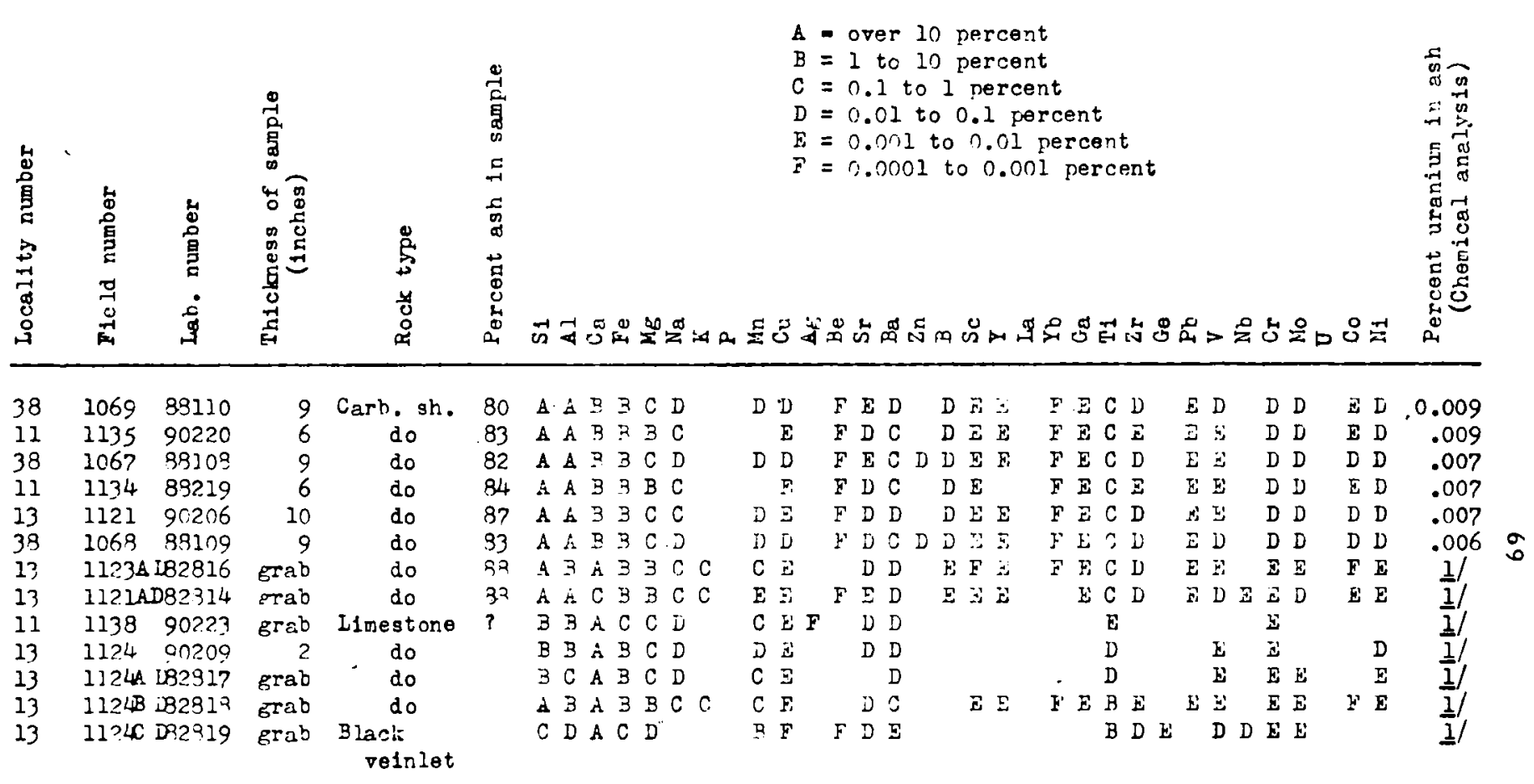




\section{APPENDIX}

Table F.--Standard sensitivities for the elements determined by the semiquantitative spectrographic method.

Elements
$\begin{array}{ll}\mathrm{Ag} & 0.0001 \\ \mathrm{Al} & 0.0001 \\ \mathrm{~B} & 0.001 \\ \mathrm{Ba} & 0.0001 \\ \mathrm{Be} & 0.0001 \\ \mathrm{Ca} & 0.001 \\ \mathrm{Co} & 0.01 \\ \mathrm{Cr} & 0.001 \\ \mathrm{Cu} & 0.0001 \\ \mathrm{Fe} & 0.001 \\ \mathrm{Ga} & 0.01\end{array}$

\begin{tabular}{|c|c|}
\hline Elements & Percent \\
\hline $\mathrm{Ge}$ & 0.001 \\
\hline$K$ & 0.1 \\
\hline La & 0.01 \\
\hline $\mathrm{Mg}$ & 0.0001 \\
\hline Mo & 0.001 \\
\hline $\mathrm{Mn}$ & 0.001 \\
\hline $\mathrm{Nb}$ & 0.01 \\
\hline $\mathrm{Na}$ & 0.1 \\
\hline $\mathrm{Ni}$ & 0.01 \\
\hline $\mathrm{P}$ & 0.1 \\
\hline $\mathrm{Pb}$ & 0.01 \\
\hline
\end{tabular}

\section{Elements Percent}

$\begin{array}{ll}\mathrm{Sc} & 0.001 \\ \mathrm{Si} & 0.0001 \\ \mathrm{Sr} & 0.01 \\ \mathrm{Ti} & 0.001 \\ \mathrm{U} & 0.1 \\ \mathrm{~V} & 0.01 \\ \mathrm{Y} & 0.001 \\ \mathrm{Yb} & 0.0001 \\ \mathrm{Zn} & 0.01 \\ \mathrm{Zr} & 0.001\end{array}$














